OPEN ACCESS

Edited by:

Ran Wang,

Institute of Plant Protection and Environmental Protection, Beijing Academy of Agricultural and Forestry

Sciences, China

Reviewed by:

Jinda Wang,

Fujian Agriculture and Forestry

University, China

Shaukat Ali,

South China Agricultural University,

China

*Correspondence:

Jelica Lazarević

jellaz@ibiss.bg.ac.rs

tThese authors share senior authorship

Specialty section: This article was submitted to Invertebrate Physiology, a section of the journal

Frontiers in Physiology

Received: 23 December 2021

Accepted: 25 January 2022

Published: 17 February 2022

Citation:

Lazarević J, Jevremović S,

Kostić I, Vuleta A, Manitašević Jovanović S, Kostić M and Šešlija Jovanović D (2022) Assessment of

Sex-Specific Toxicity

and Physiological Responses to Thymol in a Common Bean Pest

Acanthoscelides obtectus Say.

Front. Physiol. 13:842314. doi: 10.3389/fphys.2022.842314

\section{Assessment of Sex-Specific Toxicity and Physiological Responses to Thymol in a Common Bean Pest Acanthoscelides obtectus Say}

\author{
Jelica Lazarević1*t, Stojan Jevremović ${ }^{2}$, Igor Kostić ${ }^{3 \dagger}$, Ana Vuleta ${ }^{1}$, \\ Sanja Manitašević Jovanović ${ }^{1}$, Miroslav Kostić ${ }^{4}$ and Darka Šešlija Jovanović ${ }^{1 \dagger}$ \\ 1 Institute for Biological Research "Siniša Stanković" - National Institute of Republic of Serbia, University of Belgrade, \\ Belgrade, Serbia, ${ }^{2}$ Bayer d.o.o., Belgrade, Serbia, ${ }^{3}$ Institute for Multidisciplinary Research, University of Belgrade, Belgrade, \\ Serbia, ${ }^{4}$ Institute for Medicinal Plants Research "Dr. Josif Pančić", Belgrade, Serbia
}

Acanthoscelides obtectus Say (Coleoptera: Chrysomelidae: Bruchinae), is one of the most important pests of the common bean Phaseolus vulgaris L. Without appropriate management it may cause significant seed loss in storages. In search for means of environmentally safe and effective protection of beans we assessed biological activity of thymol, an oxygenated monoterpene present in essential oils of many aromatic plants. We studied contact toxicity of thymol on bean seeds and its effects on adult longevity and emergence in F1 generation. Furthermore, we determined acetylcholinesterase (AChE), superoxide dismutase (SOD), catalase (CAT), mixed-function oxidase (MFO), carboxylesterases (CarE) and glutathione S-transferase (GST) activities in response to $24 \mathrm{~h}$ exposure of beetles to sublethal and lethal thymol concentrations. Our results showed that thymol decreased adult survival, longevity and percentage of adult emergence. Higher median lethal concentration ( $\left.\mathrm{LC}_{50}\right)$ was recorded in females indicating their higher tolerance comparing to males. Overall, activities of SOD, CAT and CarE increased at sublethal and MFO increased at both sublethal and lethal thymol concentrations. On the other hand, GST and AChE activities decreased along with the increase in thymol concentrations from sublethal (1/5 of $L C_{50}, 1 / 2$ of $\left.L C_{50}\right)$ to lethal $\left(L_{50}\right)$. Enzyme responses to the presence of thymol on bean seed were sexspecific. In the control group females had lower CarE and higher SOD, CAT and GST activity than males. In treatment groups, females had much higher CAT activity and much lower CarE activity than males. Our results contribute to deeper understanding of physiological mechanisms underlying thymol toxicity and tolerance which should be taken into account in future formulation of a thymol-based insecticide.

Keywords: Acanthoscelides obtectus, seed protection, thymol, insecticidal activity, antioxidative defense, detoxification, sexual dimorphism 


\section{INTRODUCTION}

The bean weevil Acanthoscelides obtectus Say (Coleoptera: Chrysomelidae: Bruchine) is an economically important pest of leguminous crops. Beside the primary host common bean Phaseolus vulgaris $\mathrm{L}$. it can also feed on other crops belonging to 11 different genera (Johnson, 1981; Labeyrie, 1990). In a study of Szentesi (2021) 18 legume species are shown to be acceptable, and nine of them support complete development to adults even if seed coat was intact. A. obtectus originates from South America but widened its areal of distribution to Europe, North America, Australia and Africa due to human-mediated migrations and tolerance to broad range of environmental conditions (Alvarez et al., 2005). Bean infestation starts in fields by female oviposition into pods and then spreads in storages causing rapid destruction of bean seeds in subsequent generations (Schmale et al., 2002). Larvae feed inside the seeds leading to changes in their mass and nutritional quality (Keszthelyi et al., 2018). Quantitative postharvest losses in storages due to insect infestation may reach value of $30 \%$ in developing countries (Nayak and Daglish, 2018).

Chemical fumigants and contact insecticides are still the main method for storage seed protection (Obeng-Ofori, 2010). However, environmental pollution and threats to human health due to insecticide residues as well as the risk of pest resistance evolution (Guedes et al., 2017; Dar et al., 2020) forced searching for alternative management tools (reviewed in Mohapatra et al., 2015; Daglish et al., 2018; Rajendran, 2020). For example, recent studies on A. obtectus have evaluated efficacy of hermetic storage (Freitas et al., 2016), inert dusts (Floros et al., 2018; Lazarević et al., 2018; Prasantha et al., 2019), predators and parasitoids (Iturralde-García et al., 2020), insecticidal products of entomopatogenic bacteria and fungi (Rodríguez-González et al., 2018, 2020), as well as plant-derived products (Kisa et al., 2018; Jevremović et al., 2019; Hategekimana and Erler, 2020; Lazarević et al., 2020).

Among plant-derived products, essential oils (EOs) and their compounds terpenoids and phenylpropanoids exhibit various biological activities against stored product insects including toxicity and sublethal effects on behavior and physiology (reviewed in Nerio et al., 2010; Zibaee, 2011; Kim S. I. et al., 2012; Ebadollahi and Sendi, 2015; Chaudhari et al., 2021). The complex nature of essential oils and artificial blends of their compounds may slow down evolution of pest resistance, whereas low persistence of the volatiles minimizes harmful impact on the environment (Pavela, 2016; Isman, 2020). Additionally, these natural products may contribute to sustainable plant protection through synergy with chemical insecticides (Norris et al., 2018; Reynoso et al., 2018; Ruttanaphan et al., 2019).

Physiological mechanisms of EOs and EOs compounds activity against insects involve neurotoxic interference on cholinergic, GABA-ergic and octopamine pathways (Jankowska et al., 2018), and metabolic reorganization mostly at the level of xenobiotic detoxification, mitochondrial function and antioxidative defense (Liao et al., 2016; Huang et al., 2018; Gao et al., 2020). The activity of acetylcholinesterase (AChE), the enzyme which degrades neurotransmitter acethylcholine, can be inhibited by many terpenoids (López and Pascual-Villalobos,
2010, 2015; Herrera et al., 2015; Al-Nagar et al., 2020; Liu et al., 2021). EOs and EOs compounds may also decrease the activity of enzymes in the mitochondrial electron transport chain, which further provoke increase in free radicals and oxidative damage to macromolecules (Pinho et al., 2014; da Cunha et al., 2015; Kiran et al., 2017; Liao et al., 2018). To defend from oxidative stress, insects induce various enzymatic and non-enzymatic antioxidants (da Cunha et al., 2015; Kiran and Prakash, 2015a,b; Agliassa and Maffei, 2018; Chen et al., 2021). For example, dietary $\alpha$-pinene, trans-anethole and thymol elevate activities of superoxide dismutase (SOD), catalase (CAT) and glutathione S-transferase (GST) in Ephestia kuehniella Zeller larvae (Shahriari et al., 2018). SOD catalyzes the conversion of superoxide anion radical $\left(\mathrm{O}_{2}{ }^{-}\right)$into oxygen $\left(\mathrm{O}_{2}\right)$ and hydrogen peroxide $\left(\mathrm{H}_{2} \mathrm{O}_{2}\right)$ after which CAT decomposes $\mathrm{H}_{2} \mathrm{O}_{2}$ to water and $\mathrm{O}_{2}$. GST metabolizes lipid peroxides and as a major phase II detoxification enzyme catalyzes conjugation of electrophilic xenobiotics with low-molecular antioxidant glutathione. Formed conjugates are less toxic and more water soluble which facilitates their excretion. Mixed-function oxidase (MFO) and carboxylesterase (CarE), phase I detoxification enzymes involved in decomposition of exogenous toxins, can be also induced in the presence of terpenoids (Yotavong et al., 2015; Vasantha-Srinivasan et al., 2018; Gao et al., 2020; Piri et al., 2020; Subaharan et al., 2021). However, inhibition of detoxification enzymes by EOs and EOs compounds has also been reported in insects (Liao et al., 2017; Tak et al., 2017; de Souza et al., 2019; Hu et al., 2019; Shang et al., 2019; Chen et al., 2021; Gaire et al., 2021).

The present study evaluates insecticidal potential of thymol, a natural monoterpenoid phenol, against $A$. obtectus. Thymol (2isopropyl-5-methylphenol) is the major ingredient of essential oils extracted from aromatic plants belonging to families of Lamiaceae, Apiaceae, Verbenaceae, Asteraceae, Ranunculaceae, Scrophulariaceae and Saururaceae (Escobar et al., 2020). Many of these plants are used as seasonings in human nutrition and as medicinal herbs with anti-inflammatory, analgesic, antimicrobial, antioxidant and other properties (Peter and Shylaja, 2012; Mancini et al., 2015). FEMA expert panel included thymol and thymol containing essential oils in a list of "generally recognized as safe" (GRAS) natural flavors (Cohen et al., 2021). These compounds also show low toxicity to non-target organisms (Charpentier et al., 2014; Yotavong et al., 2015; Pavela et al., 2020) and various adverse effects on fitness of pest insects (Abdelgaleil et al., 2021b).

In A. obtectus thymol applied as fumigant induced high mortality and decreased adult longevity, fecundity, penetration of larvae into bean seeds and adult emergence (Regnault-Roger and Hamraoui, 1995). Our study was aimed to determine residual contact toxicity of thymol by monitoring adult survival and progeny production and to explore the physiological basis of thymol toxicity by measuring activities of AChE, SOD, CAT, MFO, CarE, and GST. Additionally, since females and males of this species differently responded to various chemical stressors (Papachristos and Stamopoulos, 2002; Papachristos et al., 2004; Lazarević et al., 2013, 2018, 2020; Šešlija Jovanović et al., 2014) we assessed if changes in survival and enzyme activities were sexspecific. 


\section{MATERIALS AND METHODS}

\section{Insects and Rearing Conditions}

Acanthoscelides obtectus used in this study originated from the laboratory population maintained on the common bean (Phaseolus vulgaris c.v. "gradištanac") seeds for more than 250 generations. During the experiment, beetles were kept in heating incubators at $27 \pm 1^{\circ} \mathrm{C}, 12 \mathrm{~h}: 12 \mathrm{~h}$ light:dark photoperiod and $55 \pm 10 \%$ relative humidity. Bean seeds were chemically untreated and frozen prior to usage to avoid any possible infestation with external pests.

\section{Residual Contact Toxicity of Thymol on Bean Seeds}

Thymol purchased from Sigma-Aldrich (cat. no. W306606) was dissolved in acetone. Bean seeds (10 g) were put in $90 \mathrm{~mL}$ glass jars and treated with $300 \mu \mathrm{L}$ of either thymol solutions or solvent (control). Five thymol concentrations were applied for females $(60,90,105,120$, and $150 \mathrm{mg} / \mathrm{kg}$ of beans) and males $(30,45,60$, 75 , and $90 \mathrm{mg} / \mathrm{kg}$ of beans). Treated seeds were mixed manually for $5 \mathrm{~min}$ and left in open jars for $20 \mathrm{~min}$ to evaporate the solvent. Then, 10 adult females or males (one day old) were introduced into the jar, covered with a piece of cloth fixed with rubber. Eight replicates per sex per thymol concentration and control (acetone) were analyzed. The number of dead insects was estimated daily until all insects died. Percentage of dead insects after $24 \mathrm{~h}$ of treatment was used to determine lethal thymol concentrations. Beetle longevity and age-specific mortality were also observed.

\section{Thymol Effects on F1 Progeny Production}

Bean seeds (20 g) were put in $200 \mathrm{~mL}$ glass jars and treated with $600 \mu \mathrm{L}$ of either thymol solution or solvent (control). Applied thymol concentrations were $30,45,60,75,90,105$, and $120 \mathrm{mg} / \mathrm{kg}$ of beans. After $5 \mathrm{~min}$ of treated seed mixing and $20 \mathrm{~min}$ of solvent evaporation, five pairs of one day old bean weevils, i.e., five females and five males, were introduced into each jar, covered with a piece of cloth fixed with rubber and kept in heating incubators until the emergence of the progeny. Emerged adults were counted daily until the end of emergence. Total number of emerged insects as well as the number of emerged females and males were used to determine the inhibition rate (IR\%) of emergence according to the formula:

$$
I R \%=\frac{N c-N t}{N c} \times 100
$$

where $\mathrm{N}_{c}$ and $\mathrm{N}_{t}$ were total numbers of emerged adults in control and treatment jars, respectively.

\section{Enzyme Assays}

Activities of enzymes (AChE, SOD, CAT, MFO, CarE, GST) were determined in female and male beetles exposed to sublethal (1/5 of $\mathrm{LC}_{50}, 1 / 2$ of $\mathrm{LC}_{50}$ ) and lethal concentrations $\left(\mathrm{LC}_{50}\right)$ of thymol for $24 \mathrm{~h}$. The enzyme extracts were prepared by pulverization of batches of 20 frozen beetles under liquid nitrogen in a mortar with the pestle. After the addition of cold $50 \mathrm{mM}$
K-phosphate buffer pH 7.4 containing $1 \mathrm{mM}$ EDTA and $1 \mathrm{mM}$ PMSF (1:10 tissue to buffer ratio), homogenates were sonicated $(2 \times 15 \mathrm{~s})$ and centrifuged at $4^{\circ} \mathrm{C}, 16,000 \times g$ for $30 \mathrm{~min}$. The supernatants were collected and used for the determination of enzymes activities and total protein content. All enzyme assays were performed at $30^{\circ} \mathrm{C}$. The total protein content was quantified according to Bradford (1976) with bovine serum albumin (BSA) as the standard and enzyme activities were expressed in units (U) per mg of proteins.

The activity of AChE was determined according to the method of Ellman et al. (1961). During the reaction, thiol groups released from substrate acetyl-thiocholine iodide (ACTH) bind to 5,5' dithio-bis(2-nitrobenzoic acid) (DTNB) and form yellow 5-thio2-nitrobenzene (TNB). The reaction was carried out in $50 \mathrm{mM}$ phosphate buffer $\mathrm{pH} 7.9$ and the change in absorbance was monitored at $406 \mathrm{~nm}\left(\varepsilon=13,330 \mathrm{M}^{-1} \mathrm{~cm}^{-1}\right)$. One enzyme unit (U) was defined as the amount of enzyme that forms $1 \mathrm{nmol}$ TNB per min.

The activity of SOD was assayed by the method of Misra and Fridovich (1972), which is based on the capacity of SOD to inhibit autoxidation of adrenaline to adrenochrome at $\mathrm{pH} 10.2$ (50 $\mathrm{mM}$ sodium carbonate buffer). The change in absorbance was monitored at $480 \mathrm{~nm}$. One unit of SOD activity was defined as the amount of enzyme causing $50 \%$ inhibition of the adrenaline autoxidation.

CAT activity was determined by the method of Claiborne (1984). The rate of hydrogen peroxide $\left(\mathrm{H}_{2} \mathrm{O}_{2}\right)$ decomposition in $50 \mathrm{mM}$ phosphate buffer $\mathrm{pH} 7.0$ was determined according to the change in absorbance at $240 \mathrm{~nm}\left(\varepsilon=43.6 \mathrm{M}^{-1} \mathrm{~cm}^{-1}\right)$. One unit of CAT activity was defined as the amount of enzyme that catalyzed the decomposition of $1 \mu \mathrm{mol}$ of $\mathrm{H}_{2} \mathrm{O}_{2}$ per min.

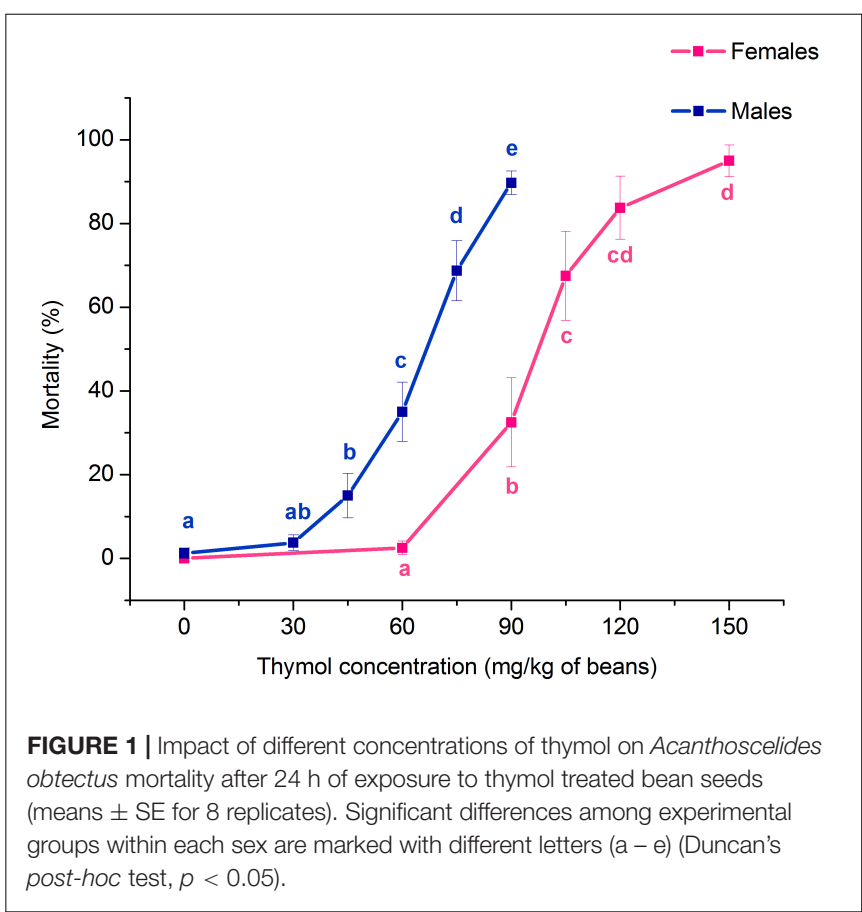


TABLE 1 | Residual contact toxicity of thymol against adult females and males of Acanthoscelides obtectus.

\begin{tabular}{|c|c|c|c|c|c|c|}
\hline & $\begin{array}{l}\text { Slope } \\
\text { (Cl) }\end{array}$ & $\begin{array}{c}\mathrm{LC}_{30} \\
(\mathrm{Cl})\end{array}$ & $\begin{array}{c}\mathrm{LC}_{50} \\
(\mathrm{Cl})\end{array}$ & $\begin{array}{c}\mathrm{LC}_{99} \\
(\mathrm{Cl})\end{array}$ & $x^{2}$ & $p$ \\
\hline Females & $\begin{array}{l}8.73 \pm 0.79 \\
(7.17,10.28)\end{array}$ & $\begin{array}{c}85.8 \\
(80.7,89.7)\end{array}$ & $\begin{array}{c}98.4 \\
(94.2,102.3)\end{array}$ & $\begin{array}{c}181.8 \\
(165.6,207.0)\end{array}$ & 3.84 & 0.279 \\
\hline Males & $\begin{array}{l}8.68 \pm 0.80 \\
(7.11,10.25)\end{array}$ & $\begin{array}{c}55.2 \\
(51.3,58.5)\end{array}$ & $\begin{array}{c}66.0 \\
(62.7,69.0)\end{array}$ & $\begin{array}{c}108.9 \\
(100.8,120.9)\end{array}$ & 1.02 & 0.795 \\
\hline
\end{tabular}

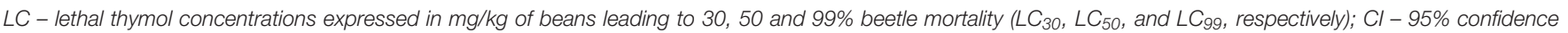
interval; $\chi^{2}$ and $P$ - Pearson's goodness-of-fit test $(d f=3)$.

The activity of MFO was quantified indirectly by the heme peroxidation method (Brogdon et al., 1997). TMBZ (3, 3', 5, $5^{\prime}$-tetra-methylbenzidine) dissolved in methanol and sodium acetate buffer $\mathrm{pH} 5.0$ was used as a hydrogen donor substrate. The reaction started with adding a drop of hydrogen peroxide. After 5 minutes of incubation absorbance was read at $630 \mathrm{~nm}$. Cytochrome $\mathrm{c}$ was used as an internal standard and the enzyme unit was expressed as pmol of cytochrome c equivalents per min.

CarE activity was determined by the method of $\mathrm{Wu}$ et al. (1998) by using p-nitrophenyl acetate (p-NA) as a substrate. The enzyme hydrolyzes acetate ester and forms p-nitrophenol (p-NP) which absorbs at $405 \mathrm{~nm}\left(\varepsilon=12,800 \mathrm{M}^{-1} \mathrm{~cm}^{-1}\right)$. The enzyme unit was defined as the amount of enzyme which generates 1 nmol of $\mathrm{p}$-NP per min.

The activity of GST was determined by the method of Habig et al. (1974). The method is based on the reaction of CDNB with the $\mathrm{SH}$ group of GSH which was performed in $100 \mathrm{mM}$ potassium phosphate buffer $\mathrm{pH}$ 6.5. The change in absorbance was measured at $340 \mathrm{~nm}\left(\varepsilon=9,600 \mathrm{M}^{-1} \mathrm{~cm}^{-1}\right)$ and the enzyme unit was defined as the amount of enzyme that generate $1 \mathrm{nmol}$ of CDNB-GSH conjugate per min.

\section{Statistical Methods}

Lethal thymol concentrations after $24 \mathrm{~h}$ of exposure were estimated by probit analysis (Finney, 1971) and their values were compared between females and males according to overlapping confidence intervals. Based on mortality data during the beetles life time Kaplan-Meier survival probability was calculated, survival analysis was performed and survival distribution was compared among thymol concentrations by log-rank test. Parameters $a$ (initial mortality) and $b$ (exponential increase in mortality over time) of the Gompertz model (instantaneous mortality at age $x=a \times e^{b x}$ ) were determined by using WinModest software and compared between control and thymol treated beetles by using the log-likelihood-ratio test (Pletcher, 1999). Also, Gompertz parameters were compared between females and males of the control group and group treated with $60 \mathrm{mg}$ of thymol/ $\mathrm{kg}$ of beans.

Kolmogorov-Smirnov test of normality and Bartlett's test for homogeneity of variances were applied on data transformed in order to achieve assumptions for parametric ANOVA. Arcus sinus square root transformation was used for the percentage of $24 \mathrm{~h}$ adult mortality and the percentage of adult emergence inhibition. Data on the number of emerged adults and adult longevity were square root transformed. Assumption of normality of distribution was violated for square root transformed female and male longevities. Accordingly, to assess the impact of thymol concentration on adult longevity we used non-parametric Kruskal-Wallis ANOVA and Dunn's posthoc test, whereas $24 \mathrm{~h}$ mortality and adult emergence were analyzed by parametric 1-way ANOVA and Duncan's post-hoc test. To reveal the significance of the differences in the number of emerged females and males we performed 1-way repeated measures ANOVA with sex as within-subject factor and thymol concentration as between-subject factor.

Enzyme activities were analyzed by 2-way ANOVA with thymol concentration and sex as fixed factors. Carboxylesterase activity was log-transformed whereas untransformed data on other enzyme activities satisfied parametric ANOVA assumptions. A posteriori comparisons (least square means contrasts) were applied to assess the significance of enzyme activity differences between sexes within each thymol concentration. Also, 1-way ANOVAs followed by Duncan's post-hoc test were carried out to reveal the significance of thymol concentration effects on enzyme activities separately in females and males. All analyses were carried out with the software Statistica 7.0 (StatSoft, Inc., Tulsa, OK, United States).

\section{RESULTS}

\section{Acute Thymol Toxicity Against Acanthoscelides obtectus}

Thymol concentration significantly affected the percentage of A. obtectus mortality both in females $\left(F_{4,35}=24.81, p<0.001\right)$ and males $\left(F_{5,42}=43.17, p<0.001\right)$. Mortality of females and males was significantly increased at concentrations equal or higher than 90 and $45 \mathrm{mg} / \mathrm{kg}$ of beans, respectively (Figure 1). Concentration-mortality response fitted the probit distribution (Pearson's test in Table 1). Higher resistance of females than males to thymol was confirmed by higher low lethal $\left(\mathrm{LC}_{30}\right)$ and lethal concentrations $\left(\mathrm{LC}_{50}, \mathrm{LC}_{99}\right)$ with non-overlapping confidence intervals.

\section{Acanthoscelides obtectus Longevity and Time-Mortality Responses to Thymol}

Exposure to thymol negatively affected A. obtectus adult longevity. Both females and males lived shorter comparing to control beetles (Kruskal-Wallis ANOVA, females: $H_{4,399}=227.68, p<0.001 ;$ males: $H_{5,479}=125.48$, $p<0.001)$. Significant longevity decrease can be observed 


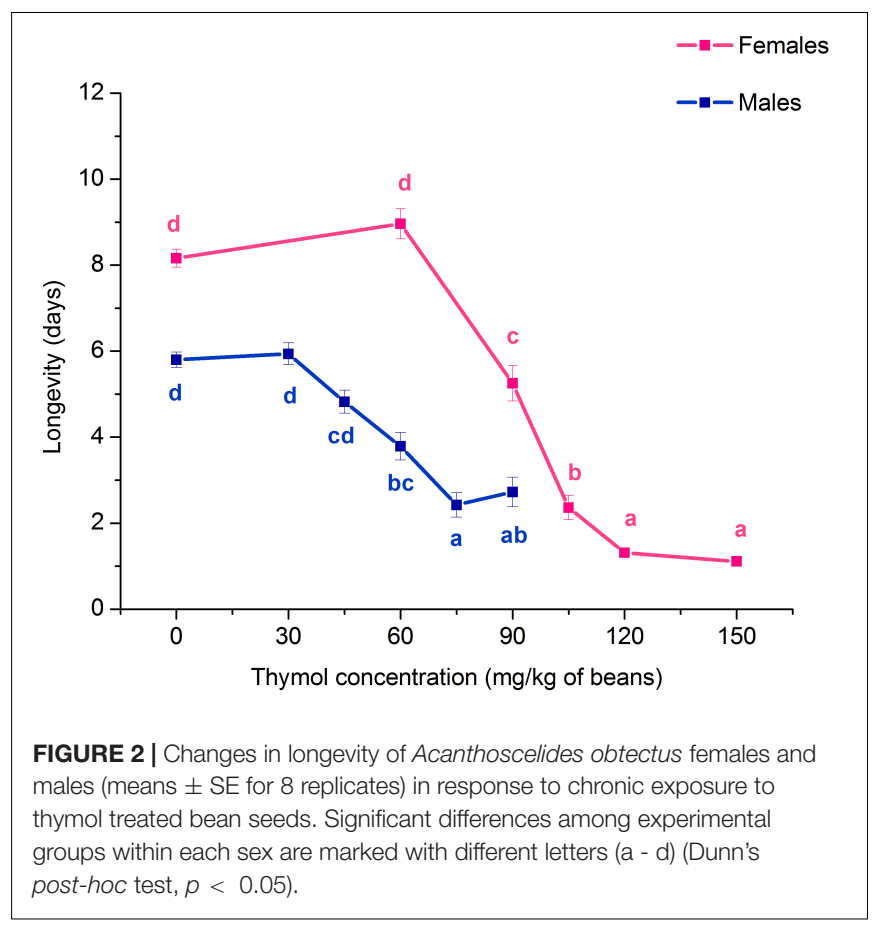

at concentrations $\geq 90 \mathrm{mg} / \mathrm{kg}$ of beans in females and $60 \mathrm{mg} / \mathrm{kg}$ of beans in males (Figure 2).

As revealed by Kaplan-Meier analysis thymol applied on bean seeds also affected survival distribution over time in females $\left(\chi^{2}=368.12, \mathrm{df}=5, p<0.001\right)$ and males $\left(\chi^{2}=58.35, \mathrm{df}=5\right.$, $p<0.001)$. Beetles from the treatment groups started to die earlier than control beetles (Figure 3) and had higher initial mortality at thymol concentrations $\geq 90 \mathrm{mg} / \mathrm{kg}$ of beans in females and $30 \mathrm{mg} / \mathrm{kg}$ of beans in males (Gompertz parameter $a$ in Table 2). This higher initial mortality was related to slower mortality increase with advanced age and higher maximum longevity (Figure 3, Gompertz parameter $b$ in Table 2). In the control group males lived shorter due to accelerated aging rate, whereas in beetles exposed to $60 \mathrm{mg}$ of thymol / $\mathrm{kg}$ of beans shorter life of males was a consequence of much higher initial mortality (higher parameter $a$ ) which could not be compensated by retarded aging (lower parameter $b$ ) (Table 2 ).

\section{Thymol Impact on Acanthoscelides obtectus Adult Emergence}

Results presented in Table 3 show that the number of emerged adults decreased significantly at concentrations $\geq 60 \mathrm{mg} / \mathrm{kg}$ of beans (female emergence: $F_{5,42}=21.12, p<0.001$; male emergence: $F_{5,42}=21.14, p<0.001$; total emergence: $\left.F_{5,42}=22.19, p<0.001\right)$. Similarly, the percentage of emergence inhibition was significantly affected by thymol concentration (females: $F_{4,35}=19.51, p<0.001$; males: $F_{4,35}=16.81, p<0.001$; females+males: $\left.F_{4,35}=18.80, p<0.001\right)$. The concentration that provoked $50 \%$ emergence inhibition was estimated to be $57.3 \mathrm{mg} / \mathrm{kg}$ of beans $(\mathrm{CI}=0.179 ; 0.201)$. Significant influence of thymol concentration on adult emergence and emergence inhibition was also confirmed by repeated measures ANOVA
$\left(F_{5,42}=22.32, p<0.001\right.$ and $F_{4,35}=19.05, p<0.001$, respectively). On average, more males than females emerged in F1 generation (within-subject sex: $F_{1,42}=8.20, p=0.007$ ) but emergence inhibition was not sex specific $\left(F_{1,35}=0.04\right.$, $p=0.846)$. Additionally, slope of thymol concentration F1 progeny number and thymol concentration - emergence inhibition response did not differ between females and males (concentration $\times$ sex interaction: $F_{5,42}=0.19, p=0.964$ and $F_{4,35}=0.50, p=0.734$, respectively).

\section{Enzyme Activities in Acanthoscelides obtectus Exposed to Sublethal and Lethal Thymol Concentrations}

The neurotoxic effect of thymol on A. obtectus adults was revealed by inhibition of AChE activity both at sublethal and lethal concentrations (Figure 4; significant "concentration" term in Table 4). The slope of AChE inhibition differed between females and males (significant "sex $\times$ concentration" term in Table 4). Influence of thymol concentration was highly significant in females $\left(F_{3,16}=18.77, p<0.001\right)$, and males $\left(\mathrm{F}_{3,16}=3.40\right.$, $p=0.044)$. At median lethal concentration $\mathrm{LC}_{50}$ AchE was inhibited about $38 \%$ in females and $15 \%$ in males (Figure 4).

On average, activities of antioxidative enzymes SOD and CAT were elevated in the presence of thymol (Figure 5; significant "concentration" term in Table 4). Shape of thymol concentration - activity response depended on sex (significant "sex $\times$ concentration" terms in Table 4) although both females (SOD: $F_{3,16}=4.6, p=0.017$; CAT: $F_{3,16}=8.35, p=0.001$ ) and males (SOD: $F_{3,16}=10.97, p<0.001$; CAT: $F_{3,16}=19.47$, $p<0.001)$ were significantly affected by thymol concentration. Activity of catalase was about 2.5 times higher in females than males across all examined concentrations. In contrast, differences in SOD activity were recorded only in control (higher activity in females) and $\mathrm{LC}_{50}$ group (higher activity in males) (Figures 5A,B).

Activity of mixed-function oxidases was elevated in treated beetles (Figure 6A; significant "concentration" term in Table 4). Both females $\left(F_{3,16}=21.93, p<0.001\right)$ and males $\left(F_{3,16}=22.88\right.$, $p<0.001)$ were significantly affected by thymol concentration but female MFO was less sensitive (Figure 6A; significant "sex $\times$ concentration" term in Table 4). Males exposed to thymol had higher MFO activity than females (Figure 6A; significant "sex" term in Table 4).

Carboxylesterase activity was induced at sublethal thymol concentrations (Figure 6B; significant "concentration" term in Table 4). Significant thymol influence was detected both in females $\left(F_{3,16}=5.38, p=0.009\right)$ and males $\left(F_{3,16}=17.49\right.$, $p<0.001)$ but induction was more expressed in males than females (Figure 6B; significant "sex $\times$ concentration" term in Table 4). At all examined concentrations CarE activity was higher in males than females (Figure 6B; significant "sex" term in Table 4).

Inhibition of glutathione S-transferase activity by thymol is another possible mechanism of its toxicity (Figure 6C; significant "concentration" term in Table 4). Both females $\left(F_{3,16}=136.13\right.$, $p<0.001)$ and males $\left(F_{3,16}=30.73, p<0.001\right)$ were significantly 

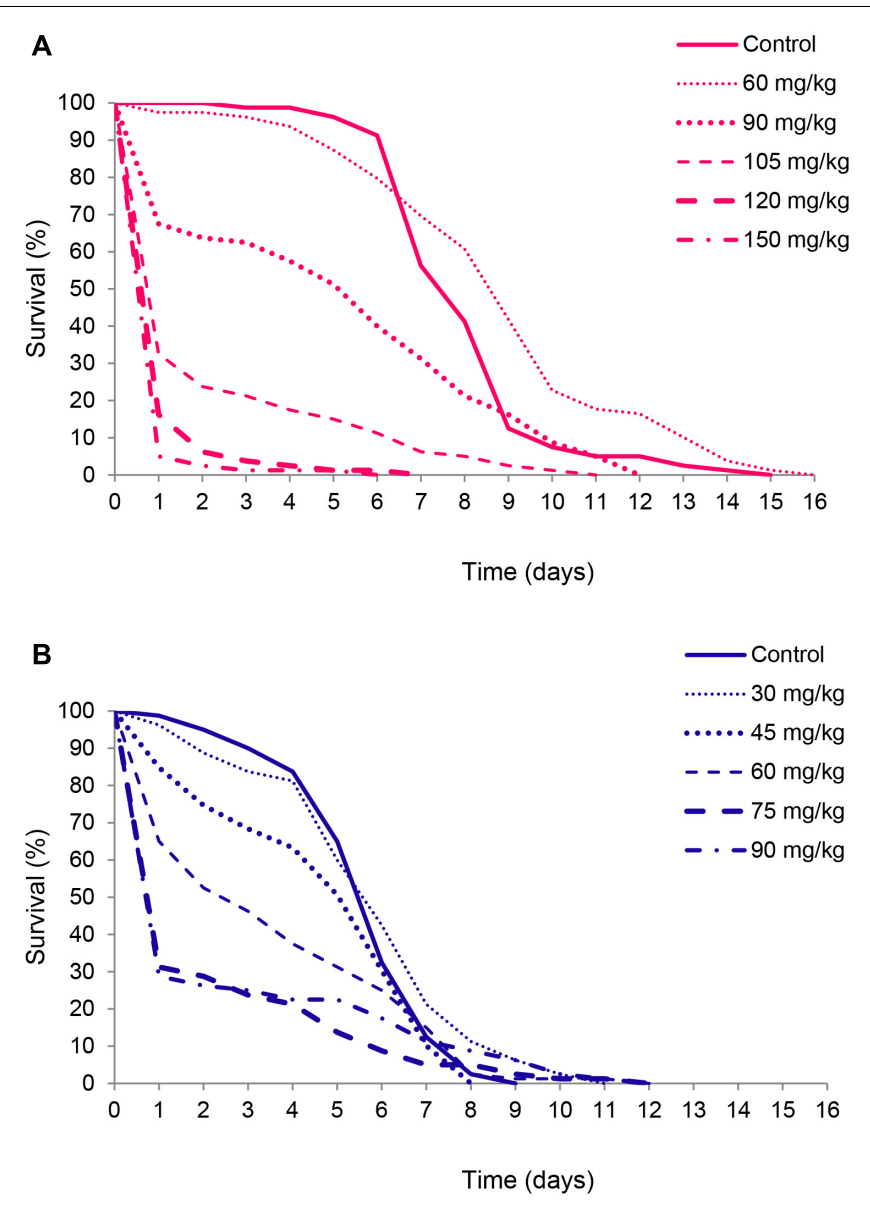

FIGURE 3 | Survival curves for female (A) and male Acanthoscelides obtectus (B) exposed to different thymol concentrations.

affected by thymol concentration but inhibition was steeper in females than males (Figure 6C; significant "sex $\times$ concentration" term in Table 4). Control and $1 / 5$ of $\mathrm{LC}_{50}$ females had about $40 \%$ higher GST activity than males, whereas no difference could be recorded at $\mathrm{LC}_{50}$ (Figure $6 \mathrm{C}$ ).

\section{DISCUSSION}

\section{Adverse Effects of Thymol on Adult Fitness Traits}

Similar to the results on residual contact toxicity of thyme EO against the bean weevil (Lazarević et al., 2020) we found that its major compound thymol also significantly affected $24 \mathrm{~h}$ mortality and longevity of females and males, and progeny production in F1 generation. The ratio of median lethal concentrations obtained for thymol and thyme EO (98.4 vs. $255.0 \mathrm{mg} / \mathrm{kg}$ of beans in females and 66.0 vs. $172.2 \mathrm{mg} / \mathrm{kg}$ of beans in males) corresponds to thymol concentration of $43.52 \%$ in thyme EO (Jevremović et al., 2019) and suggests that thymol was the major determinant of bean weevil mortality induced by thyme EO. It appeared that other EO compounds either had negligible impact on the acute toxicity of EO or some compounds contribution counteracted the antagonistic effects of others. In difference to our results studies on fumigant toxicity of thyme EO containing 47.5\% thymol (Regnault-Roger et al., 1993) and pure thymol (Regnault-Roger and Hamraoui, 1995) point to the significant contribution of other compounds. Using different bean weevil populations and different modes of botanical application may account for disagreement between results of the studies. Besides, although both EOs were extracted from thyme belonging to thymol chemotype their composition was different. For example, thyme EO from the study of Regnault-Roger and colaborators contained caryophyllene, bicyclic sesquiterpene, which had both fumigant and residual toxic effects on stored product insects (Lee et al., 2008; Sun et al., 2020).

On the other hand, ratio of median effective concentration $\left(\mathrm{EC}_{50}\right)$ for adult emergence inhibition rate on thymol $(57.3 \mathrm{mg} / \mathrm{kg}$ of beans) and thyme EO (65.7 mg/kg of beans, Lazarević et al., 2020) suggests an important role of other compounds in reducing adult emergence. Since pure thymol seems to affect F1 progeny number mainly through the adverse effect on male survival (similarity of $\mathrm{EC}_{50}$ value for adult emergence inhibition to $\mathrm{LC}_{50}$ for males on thymol) it is possible that other compounds in thyme EO additionally reduced emergence through adverse effects on mating, fecundity, larval penetration into seeds and/or preadult 
survival. Even sublethal concentrations of monoterpenes could have a significant impact on fitness traits and behavior of the bean weevil (Regnault-Roger and Hamraoui, 1995; Jevremović et al., 2019; Hategekimana and Erler, 2020) and other pests (Hummelbrunner and Isman, 2001; Wang et al., 2009; Tak and Isman, 2017; de Melo et al., 2018; Abdelgaleil et al., 2021a; Barbosa et al., 2021; de Andrade Brito et al., 2021; Ruiz et al., 2021). Because thymol also affects bean weevil fitness traits (Regnault-Roger and Hamraoui, 1995) and deters oviposition (Jevremović et al., 2019) we suppose that various synergistic and antagonistic interactions of thymol with other monoterpenes might take part in determining the number of emerged adults. In other pest species such interactions can affect repellence, feeding deterrence, female attraction to males, egg viability, adult emergence and locomotion (Singh et al., 2009; Tak and Isman, 2017; Youssefi et al., 2019; Ataide et al., 2020; López et al., 2021).

Insecticidal, repellent, antifeedant, oviposition deterrent and growth reducing effects of thymol have been confirmed in stored products (Kim et al., 2010; Szczepanik et al., 2012; Brari and Thakur, 2015; Oliveira et al., 2017, 2018; Shahriari et al., 2017; Wahba et al., 2018; da Camara et al., 2022), agricultural (Hummelbrunner and Isman, 2001; Wilson and Isman, 2006; Pavela, 2011a; Koul et al., 2013; Lima et al., 2020; Valcárcel et al., 2021) and medically important pest insects (Pavela, 2011b; Zahran and Abdelgaleil, 2011; Govindarajan et al., 2013; Youssefi et al., 2019). Influence of thymol on stored products insects depends on insect species, mode of application and sex. For example, in residual contact assays, Tribolium castaneum was more sensitive than Sitophilus oryzae (Kanda et al., 2017), whereas in fumigant assays efficacy of thymol was equal in these species (Brari and Thakur, 2015). Relative ranking of terpene efficacy also depended on the mode of application. Comparisons of thymol and linalool revealed similar toxicity and oviposition inhibition effect of thymol against the bean weevil in fumigant assay (Regnault-Roger and Hamraoui, 1995), whereas in residual contact assays thymol was more effective in reducing survival and oviposition (Jevremović et al., 2019). About ten times higher vapor pressure of linalool than thymol $(0.157$ and $0.016 \mathrm{mmHg}$, respectively) may account for such a relationship. This result is consistent with the findings of other authors that thymol bioactivity is superior in contact assays (Waliwitiya et al., 2005; Hieu et al., 2014; Wahba et al., 2018).

\section{Thymol Toxicity Is Sex-Specific}

Bean weevil females are more tolerant to monoterpenes and essential oils (Regnault-Roger and Hamraoui, 1995; Papachristos and Stamopoulos, 2002; Papachristos et al., 2004; Lazarević et al., 2020), which is confirmed in our study with residual contact toxicity of thymol where we recorded higher median lethal concentration and lower initial mortality in females than males. In other insect species, females are usually more tolerant to plant-derived compounds (Yeom et al., 2012; Theou et al., 2013; Jang et al., 2017; Park et al., 2017; Pavela et al., 2021). Sex differences depend on applied compounds and the method of application. Jang et al. (2017) detected higher tolerance of female Drosophila suzuki to topically applied citronellal, citronellol and
TABLE 2 | Gompertz mortality parameters ( $a$ - initial mortality; $b$ - exponential increase in mortality with age) and 95\% confidence intervals $(\mathrm{Cl})$ in Acanthoscelides obtectus females and males exposed to different thymol concentrations.

\begin{tabular}{lcccc}
\hline & \multicolumn{4}{c}{ Gompertz mortality parameters } \\
\cline { 2 - 5 } $\begin{array}{l}\text { Concentration } \\
\text { (mg/kg of beans) }\end{array}$ & $\boldsymbol{a}\left(\mathbf{x ~ 1 0 ^ { - 2 } )}\right.$ & $\mathbf{( C I )}$ & $\boldsymbol{b}$ & $\mathbf{( C I )}$ \\
\hline Females & & & & \\
0 & & & & \\
60 & 1.09 & $(0.61,1.95)$ & 0.40 & $(0.34,0.47)$ \\
90 & 1.35 & $(0.74,2.46)$ & $0.30^{*}$ & $(0.25,0.37)$ \\
105 & $9.48^{*}$ & $(6.08,14.77)$ & $0.15^{*}$ & $(0.10,0.25)$ \\
\hline Males & $61.63^{*}$ & $(46.24,82.14)$ & $0.19^{*}$ & $(0.09,0.41)$ \\
0 & & & & \\
30 & 0.72 & $(0.33,1.57)$ & $0.70^{C}$ & $(0.58,0.84)$ \\
45 & $2.49^{*}$ & $(1.41,4.40)$ & $0.41^{*}$ & $(0.33,0.51)$ \\
60 & $3.60^{*}$ & $(1.96,6.61)$ & $0.45^{*}$ & $(0.34,0.58)$ \\
\hline
\end{tabular}

Significant differences from the control group are marked with asterisks (loglikelihood ratio test, $d f=1, p<0.05)$. Significant differences between females and males of control and $60 \mathrm{mg}$ of thymol / kg of beans treatment group are marked with $B(p<0.01)$ and $C(p<0.001)$.

isopulegol, but not after fumigant application. Only essential oils rich in $\alpha$-pinene were more toxic to Musca domestica males (Pavela et al., 2021). In the bean weevil, females were about 3.5 times more resistant to $\alpha$-terpineol and only 1.2 times more resistant to $\alpha$-pinene (Papachristos et al., 2004). Likewise, bean weevil females were about 5 times more resistant to Mentha microphylla EO and 1.5 times more resistant to Lavandula hybrida EO (Papachristos and Stamopoulos, 2002) and thymol (present results). Possible explanations of sexual dimorphism in toxicity of plant-derived compounds against bean weevil are differences in body size and cuticle composition (Tucić et al., 1996; Gołebiowski et al., 2008) as well as differences in physiology (Šešlija et al., 1999; Lazarević et al., 2012, 2020; Arnqvist et al., 2017; Zhang et al., 2020) that may affect compound bioavailability and bean weevils' innate ability to cope with chemical stressors.

Our results showing a lower exponential increase in mortality with age in thymol treatment groups and higher maximum longevity at sublethal thymol concentrations imply that individuals that survived after $24 \mathrm{~h}$ of exposure possibly had and/or induced some kind of defense responses. To explore mechanisms of thymol toxicity and tolerance, we determined the activity of six enzymes and found that thymol gradually inhibited activities of AChE and GST, elevated activities of SOD, CAT and CarE at sublethal concentrations and MFO at both sublethal and lethal concentrations. Generally, insects resistant to chemical insecticides and plant-derived compounds have higher activities of AChE, SOD and detoxification enzymes (Attia et al., 2017; Roy and Prasad, 2018; Akami et al., 2019; Senthil-Nathan, 2020). In agreement with this, we found that in the absence of thymol females, the more tolerant sex, contained a higher level of lowmolecular thiols (Lazarević et al., 2020) and had higher activities of SOD, CAT and GST (present results). 
TABLE 3 | Adult emergence in F1 generation and emergence inhibition (means \pm SE for 8 replicates) in Acanthoscelides obtectus depending on thymol concentration (Conc) in parental generation.

\begin{tabular}{|c|c|c|c|c|c|c|}
\hline \multirow{2}{*}{$\begin{array}{l}\text { Thymol } \\
\text { Conc (mg/kg of beans) }\end{array}$} & \multicolumn{3}{|c|}{ Number of emerged adults } & \multicolumn{3}{|c|}{ Emergence inhibition (\%) } \\
\hline & Females & Males & Total & Females & Males & Total \\
\hline 0 & $43.5 \pm 6.6^{c}$ & $47.5 \pm 5.2^{\mathrm{C}}$ & $91.0 \pm 11.3^{\mathrm{c}}$ & & & \\
\hline 30 & $48.4 \pm 3.4^{c}$ & $55.1 \pm 6.3^{c}$ & $103.5 \pm 9.3^{c}$ & $-11.2 \pm 7.8^{a}$ & $-16.1 \pm 13.3^{a}$ & $-13.7 \pm 10.2^{a}$ \\
\hline 45 & $33.9 \pm 4.6^{c}$ & $35.5 \pm 4.0^{\mathrm{C}}$ & $69.4 \pm 8.3^{c}$ & $22.1 \pm 10.5^{b}$ & $25.3 \pm 8.4^{b}$ & $23.8 \pm 9.1^{b}$ \\
\hline 60 & $18.6 \pm 5.9^{b}$ & $19.5 \pm 5.8^{b}$ & $38.1 \pm 11.6^{b}$ & $57.2 \pm 13.6^{c}$ & $58.9 \pm 12.1^{\mathrm{bc}}$ & $58.1 \pm 12.7^{b}$ \\
\hline 75 & $5.8 \pm 2.9^{a}$ & $8.9 \pm 4.1^{a}$ & $14.6 \pm 6.7^{\mathrm{a}}$ & $86.8 \pm 6.7^{d}$ & $81.3 \pm 8.7^{\mathrm{cd}}$ & $83.9 \pm 7.4^{c}$ \\
\hline 90 & $3.4 \pm 1.9^{a}$ & $3.9 \pm 1.8^{a}$ & $7.3 \pm 3.7^{a}$ & $92.2 \pm 4.4^{d}$ & $91.8 \pm 3.9^{d}$ & $92.0 \pm 4.0^{\mathrm{C}}$ \\
\hline
\end{tabular}

Values marked with different letters ( $a, b, c, d)$ within columns indicate significant differences among treatments (Duncan's post-hoc test, $p<0.05)$.

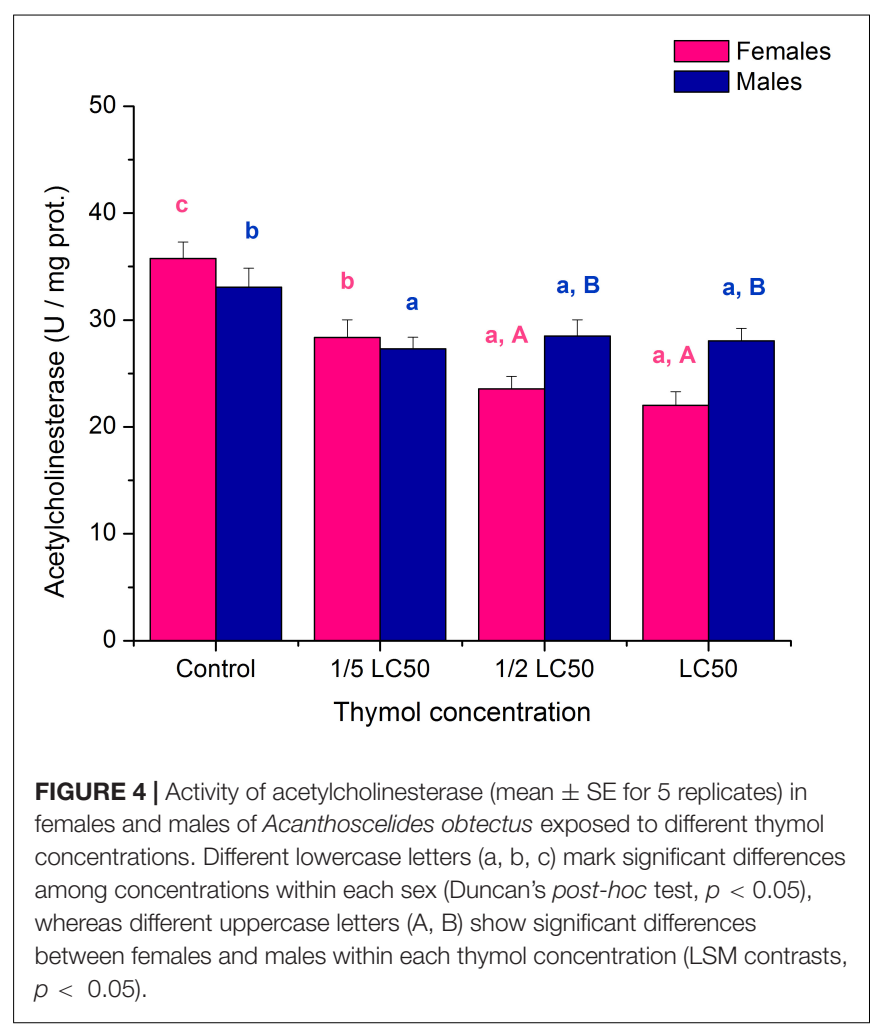

\section{Role of Antioxidative Enzymes in Tolerance to Thymol}

After exposure to sublethal thymol concentrations, SOD increased both in females and males whereas at lethal concentration it was increased only in males. SOD responds first to oxidative stress induced by xenobiotics and protects cells from dangerous free radicals. Without efficient scavenging of its product of reaction $\mathrm{H}_{2} \mathrm{O}_{2}$ by catalase and other peroxidases, it may damage macromolecules, accelerate aging and reduce insect survival and longevity. For instance, bean weevil females exposed to thyme essential oil had lower a level of damaged lipids (Lazarević et al., 2020). In consistence with our results, SOD and CAT were elevated by thymol in Ephestia kuehniella larvae (Shahriari et al., 2018), by carvacrol, p-cymene and $\gamma$-terpinene in S. littoralis larvae (Agliassa and Maffei, 2018), by carvacrol in
Lymantria dispar larvae (Chen et al., 2021), by ethanolic extract of Acalypha wilkesiana leaves in Callosobruchus maculatus adults (Oni et al., 2019) and by Boswellia carterii EO in adults of two Callosobruchus species (Kiran et al., 2017). SOD and CAT responses to botanicals may vary depending on insect species, duration of exposure, botanical type and concentration. Several studies have shown that more resistant species had higher SOD and CAT activity, higher induction of activity and/or higher CAT to SOD ratio (Kiran et al., 2017; Petrović et al., 2019). Also, in some species, botanicals can reduce SOD and/or CAT activity at high concentrations (Oni et al., 2019; Rajkumar et al., 2019).

Here we recorded higher CAT activity and CAT to SOD activity ratio in females across all examined thymol concentrations that could account for sex-specific differences in tolerance to thymol. Similar result was obtained in A. obtectus populations selected for early and late reproduction (Šešlija et al., 1999) indicating that a higher CAT and CAT to SOD ratio is characteristic of this species. Tasaki et al. (2017) suggested that females of eusocial Isoptera and Hymenoptera have high CAT activity whereas in solitary insects CAT activity is lower in females than males. However, there are also examples of higher CAT activity in females of solitary species under control (Sharma et al., 1995) and stressful conditions (Rovenko et al., 2015; Manna et al., 2020; Wang et al., 2020). Several studies have shown that $\mathrm{CAT}$ accumulates in insect ovaries providing protection to developing oocytes from oxidative damage (e.g., de Jong et al., 2007; Diaz-Albiter et al., 2011). We speculate that such mechanism might contribute to higher CAT activity in A. obtectus females which emerge with about 30 mature chorionated eggs in the lateral oviduct (Leroi, 1981). In the absence of mating antioxidants accumulated in eggs would be fully available for defense against xenobiotics.

\section{Thymol Inhibits Activities of AChE and GST}

Our observation about inhibition of neurotransmitter enzyme AChE and detoxification enzyme GST by thymol in bean weevil females and males agrees with findings of other studies on physiological mechanisms of monoterpenes and essential oils toxicity (Mojarab-Mahboubkar et al., 2015; Liao et al., 2016, 2017; Agliassa and Maffei, 2018; Yang et al., 2018; Chen et al., 2021; Fouad and Abotaleb, 2021). Inhibition of AChE leads 
TABLE 4 | F and $p$ values from 2-way ANOVA testing significance of main and interaction effects of sex and thymol concentration on activities of acetylcholinesterase (AChE), superoxide dismutase (SOD), catalase (CAT), mixed-function oxidase (MFO), carboxylesterase (CarE), and glutathione S-transferase (GST) in Acanthoscelides obtectus.

\begin{tabular}{|c|c|c|c|c|c|c|c|c|c|c|c|c|}
\hline \multirow{2}{*}{$\begin{array}{l}\text { Source of } \\
\text { variation }\end{array}$} & \multicolumn{2}{|c|}{ AChE } & \multicolumn{2}{|c|}{ SOD } & \multicolumn{2}{|c|}{ CAT } & \multicolumn{2}{|c|}{ MFO } & \multicolumn{2}{|c|}{ CarE } & \multicolumn{2}{|c|}{ GST } \\
\hline & $\mathbf{F}$ & $p$ & $\mathbf{F}$ & $p$ & $\mathbf{F}$ & $p$ & $\mathbf{F}$ & $p$ & $\mathbf{F}$ & $p$ & $\mathbf{F}$ & $p$ \\
\hline $\begin{array}{l}\text { Sex } \\
\text { (df: 1, 32) }\end{array}$ & 3.2 & 0.082 & 0.0 & 0.935 & 2366.0 & $<0.001$ & 31.4 & $<0.001$ & 682.7 & $<0.001$ & 22.5 & $<0.001$ \\
\hline $\begin{array}{l}\text { Concentration } \\
\text { (df: } 3,32 \text { ) }\end{array}$ & 17.6 & $<0.001$ & 9.7 & $<0.001$ & 19.8 & $<0.001$ & 41.6 & $<0.001$ & 21.3 & $<0.001$ & 150.1 & $<0.001$ \\
\hline $\begin{array}{l}\text { Sex } \times \text { Concentration } \\
(\mathrm{df}: 3,32)\end{array}$ & 4.6 & 0.009 & 8.6 & $<0.001$ & 1.2 & 0.329 & 3.4 & 0.029 & 7.0 & $<0.001$ & 43.6 & $<0.001$ \\
\hline
\end{tabular}

Significant effects are marked in bold.

to accumulation of acetylcholine at nerve synapses, and thus permanent conduction of nerve impulses, ataxia, convulsions and death (Rattan, 2010). AChE activity was more reduced in females than males so that males had higher activity at thymol concentration $1 / 2$ of $\mathrm{LC}_{50}$ and $\mathrm{LC}_{50}$. In difference to our results, AChE of female adults of Blatella germanica and Drosophila suzuki were less sensitive to in vitro inhibition with thymol (Yeom et al., 2012; Park et al., 2016). The discrepancy between toxicity and AChE inhibition by botanical insecticides suggests differences in other neurological or enzymatic target sites. A weak correlation has been found between AChE activity and insecticide resistance in D. melanogaster (Charpentier and Fournier, 2001). Therefore, the relationship between AChE activity and resistance to chemical stress may depend on insect species and population or applied compound. For example, although more resistant to fumigation with lemongrass essential oil AChE activity in treated females of Callosobrucus maculatus was lower than in males (de Souza et al., 2019). To fully understand AChE-thymol resistance relationship further researches are needed to reveal how thymol affects the level of cholinergic and non-cholinergic $\mathrm{AChE}$ isoforms. Non-cholinergic AChE is important for insect fecundity and defense against xenobiotics, and, compared to cholinergic isoform, exhibits lower catalytic efficiency and higher resistance to inhibiton by insecticides (Kim Y. H. et al., 2012; Kim et al., 2014; Lu et al., 2012; Hwang et al., 2014; Lee et al., 2015; Kim and Lee, 2018). Therefore, a higher level of protective noncholinergic isoform might provide higher thymol resistance to females despite the lower activity. Several studies have shown sexdependant relative expression of genes encoding the two isoforms (Zhao et al., 2013; Salim et al., 2017).

Inhibition of GST by thymol is an important feature from the pest management point of view because it could interfere with the detoxification in insects and lead to enhanced activity of conventional insecticides (Ismail, 2021). In Trichoplusia ni larvae, topical application of thymol inhibited GST activity by $41 \%$ (Tak et al., 2017), whereas topical application of thymol on larvae of Plutella xylostella (Kumrungsee et al., 2014), and oral administration in Ephestia kuehniella (Shahriari et al., 2018) and Tuta absoluta (Piri et al., 2020) increased GST activity. At $\mathrm{LC}_{50}$ of thymol we obtained that there was no difference in GST activity between females and males. However, because initial activity in control females was higher, a higher percentage of inhibition was recorded in females than males (58 vs. $35 \%$ ).
Sexual dimorphism in detoxification enzyme activity has also been revealed in other studies where pest insects were exposed to plant-derived compounds. In C. maculatus GST, p-NPA esterase and $\alpha$-esterase were not affected by lemongrass oil, whereas $\beta$-esterase was inhibited only in females (de Souza et al., 2019).

\section{Thymol Increases Activities of Phase I Detoxification Enzymes}

Two enzymes involved in the phase I detoxification, CarE and MFO, increased the activity in response to thymol suggesting that they could have an important role in thymol metabolism in the bean weevil females and males. Further investigations are needed to elucidate how bean weevils detoxify thymol. In mammals, the majority of thymol is rapidly excreted unchanged or as a conjugate but oxidation of methyl and isopropyl groups also occurred (Austgulen et al., 1987). In difference to our results, thymol did not change the activity of CarE and MFO in Trichoplusia ni (Tak et al., 2017) which larvae excreted thymol bound to glucose without the change in its monoterpenoid structure (Passreiter et al., 2004). Highly diverse results have been obtained in other insect species where thymol had insignificant effect on esterase and MFO activities (Yotavong et al., 2015) or provoked their induction (Boncristiani et al., 2012; Kumrungsee et al., 2014; Piri et al., 2020) or inhibition (Waliwitiya et al., 2012; Shahriari et al., 2017; Gaire et al., 2021).

Comparison between thymol treated females and males revealed that males had higher CarE and MFO activity and provoked activity increase at lower thymol concentrations than females. It is not clear how detoxification enzyme activity variation contributes to the higher tolerance of females to insecticides. For example, females of Helopeltis theivora that are more tolerant to organophosphates had similar MFO activity to males and higher activity of $\alpha$ esterase and GST (Roy and Prasad, 2018). Females of tortricid species Lobesia botrana and Grapholita molesta that are more tolerant to neonicotinoid insecticide thiacloprid and less tolerant to organophosphate insecticide chloropyrifos, exhibited sex-specific differences in detoxification enzymes (NavarroRoldán et al., 2017, 2020). Namely, females of L. botrana had higher activities of MFO and GST and lower sensitivity of esterase to specific inhibitor DEF, whereas G. molesta females exhibited faster inhibition of MFO with specific 


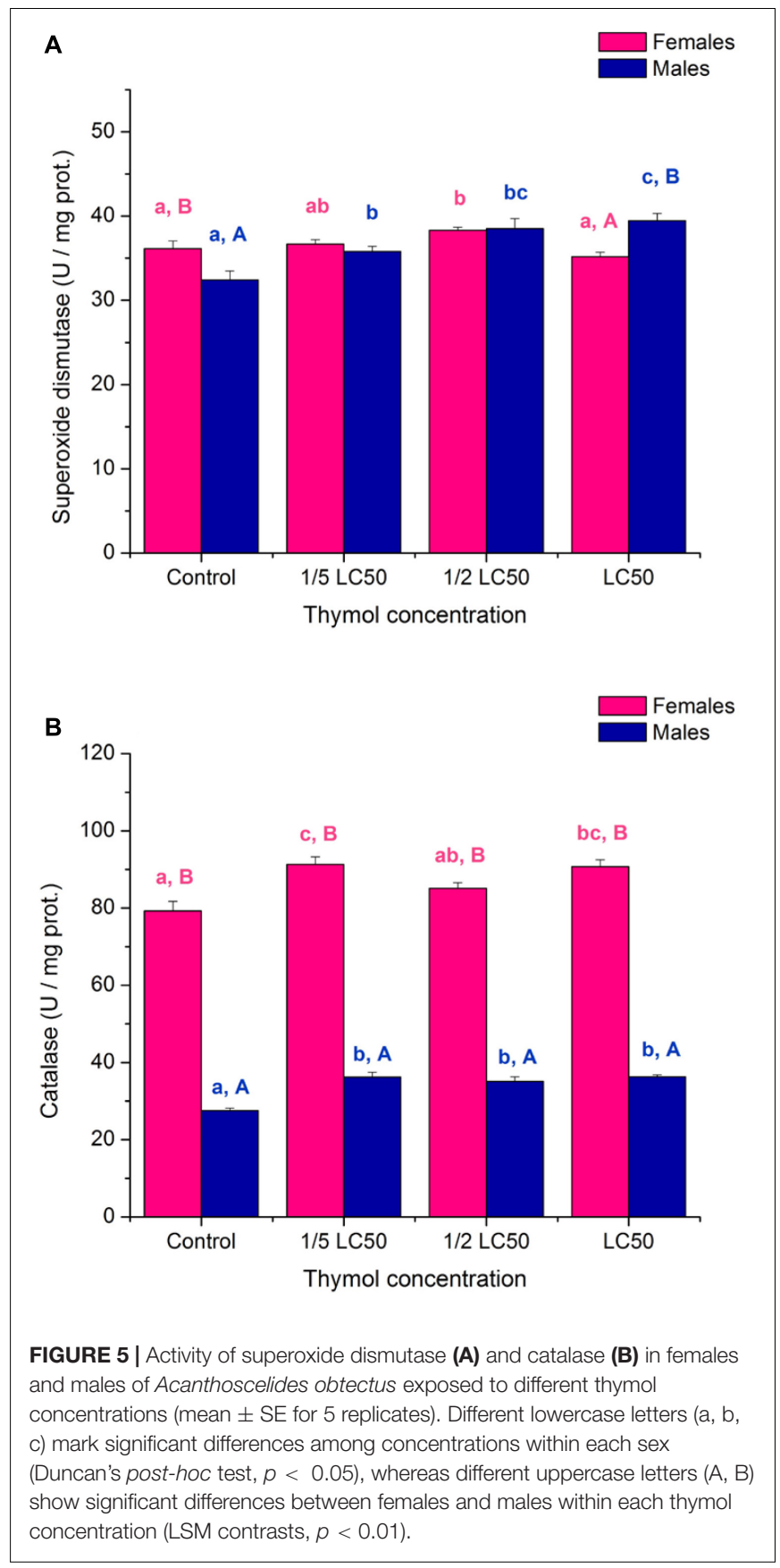

inhibitor PBO. In C. macullatus treated with lemongrass oil females had higher p-NPA esterase activity (de Souza et al., 2019). Evidently, our results on lower activity of detoxification enzymes in more tolerant sex disagree with other studies on chemical and botanical insecticides. This may suggest an involvement of other mechanisms of tolerance such as better behavioral avoidance of a toxic compound or cuticle structure which slows-down thymol penetration (Panini et al., 2016). Besides, esterases and MFO are multifunctional enzymes encoded by a large number of genes organized into families (Feyereisen, 2012; Montella et al., 2012). Change in
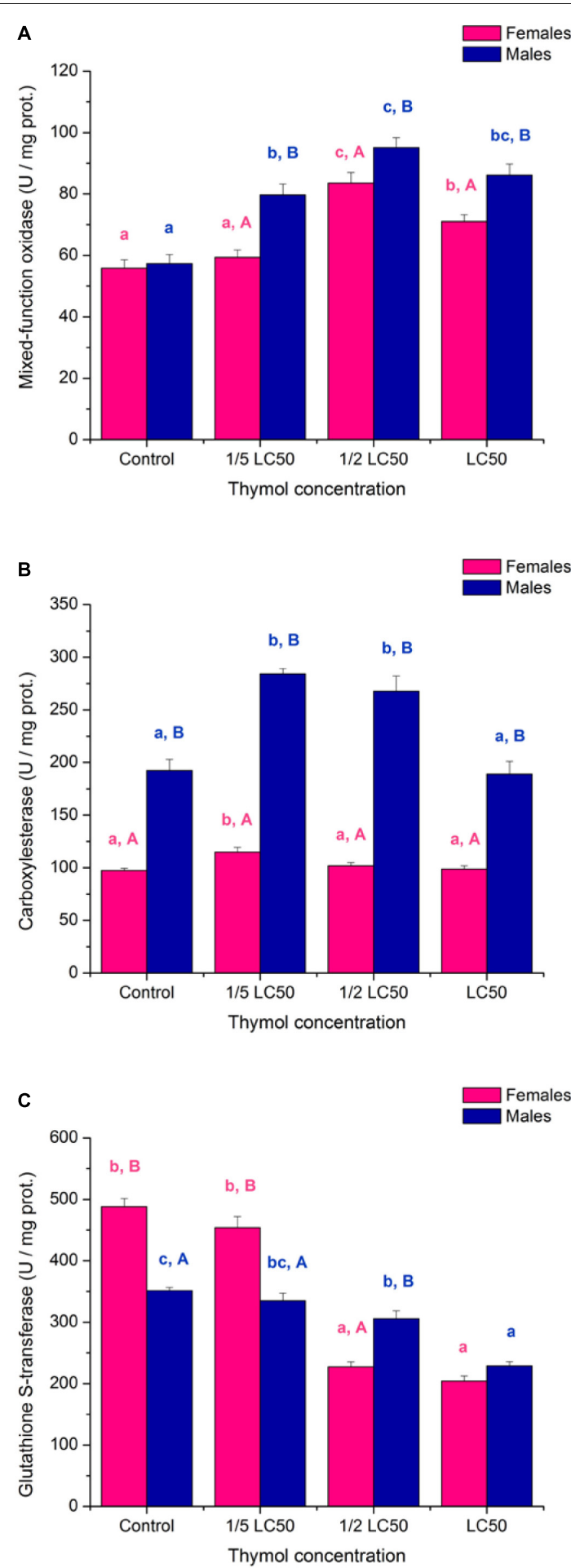

FIGURE 6 | Activity of mixed-function oxidases (A), carboxylesterase (B) and glutathione S-transferase (C) in females and males of Acanthoscelides obtectus exposed to different thymol concentrations (means \pm SE for 5 replicates). Different lowercase letters ( $a, b, c)$ mark significant differences among concentrations within each sex (Duncan's post-hoc test, $p<0.05$ ), whereas different uppercase letters $(A, B)$ show significant differences between females and males within each thymol concentration (LSM contrasts, $p<0.05)$ 
detoxification gene expression in response to xenobiotics is sexbiased and can be related to sex-specific differences in xenobiotic metabolism or other sex-specific physiological functions such as the production of pheromones and hormones by MFO and odorant degradation by esterases (Le Goff et al., 2006; Robert et al., 2013; Liu et al., 2019). High CarE activity that we recorded in male weevils might be related to its role in reproduction. It is known that carboxylesterases are overexpressed in the male reproductive tract of insects where they provide protection against xenobiotics and take part in sperm differentiation, maturation and function (Mikhailov and Torrado, 1999, 2000). In agreement with our results much higher esterase activity in males than females have been detected in whole body homogenates of Lygus hesperus (Zhu and Brindley, 1990) and abdomens of Grapholita molesta (de Lame et al., 2001) and Cydia pomonella (Fuentes-Contreras et al., 2007).

\section{Conclusion}

In conclusion, we showed insecticidal activity of thymol against the bean weevil. Since thymol has been approved by the Environmental protection agency for use on food crops (EPA Code 080402, 2021) and has many human health promoting effects (de Alvarenga et al., 2021) it can be safely used as a contact insecticide on bean seeds. Results on bean weevil physiological responses have implications for designing of future thymol-based insecticides. Inhibition of AChE is responsible for fast mortality response. However, thymol-induced inhibition was weak and thus involvement of other neurotoxicity and/or metabolic targets cannot be excluded. Due to inhibition of GST thymol can be used to synergize effects of chemical insecticides for which GST activity is crucial and thus reduce applied doses of these dangerous

\section{REFERENCES}

Abdelgaleil, S. A. M., Gad, H. A., Ramadan, G. R., El-Bakry, A. M., and El-Sabrout, A. M. (2021b). Monoterpenes: chemistry, insecticidal activity against stored product insects and modes of action-a review. Int. J. Pest Manag. 2, 1-23. doi: 10.1080/09670874.2021.1982067

Abdelgaleil, S. A. M., Al-Nagar, N. M., Abou-Taleb, H. K., and Shawir, M. S. (2021a). Effect of monoterpenes, phenylpropenes and sesquiterpenes on development, fecundity and fertility of Spodoptera littoralis (Boisduval). Int. J. Trop. Insect Sci. 2, 1-9. doi: 10.1007/s42690-021-00539-y

Agliassa, C., and Maffei, M. E. (2018). Origanum vulgare terpenoids induce oxidative stress and reduce the feeding activity of Spodoptera littoralis. Int. J. Mol. Sci. 19:2805. doi: 10.3390/ijms19092805

Akami, M., Njintang, N. Y., Gbaye, O., Niu, C. Y., and Nukenine, E. N. (2019). Comparative expression of two detoxification genes by Callosobruchus maculatus in response to dichlorvos and Lippia adoensis essential oil treatments. J. Pest Sci. 92, 665-676. doi: 10.1007/s10340-018-01075-4

Al-Nagar, N. M., Abou-Taleb, H. K., Shawir, M. S., and Abdelgaleil, S. A. (2020). Comparative toxicity, growth inhibitory and biochemical effects of terpenes and phenylpropenes on Spodoptera littoralis (Boisd.). J. Asia-Pac. Entomol. 23, 67-75. doi: 10.1016/j.aspen.2019.09.005

Alvarez, N., McKey, D., Hossaert-Mckey, M., Born, C., Mercier, L., and Benrey, B. (2005). Ancient and recent evolutionary history of the bruchid beetle, Acanthoscelides obtectus Say, a cosmopolitan pest of beans. Mol. Ecol. 14, 1015-1024. doi: 10.1111/j.1365-294X.2005.02470.x

Arnqvist, G., Stojković, B., Rönn, J. L., and Immonen, E. (2017). The pace-of-life: A sex-specific link between metabolic rate and life history in bean beetles. Funct. Ecol. 31, 2299-2309. doi: 10.1111/1365-2435.12927 compounds. Since thymol induce the activity of MFO and CarE future formulations of thymol-based insecticides should involve inhibitors of these enzymes. Sex-specific differences in tolerance to thymol and sex-specific physiological responses to thymol exposure (especially high CAT and CAT to SOD activity ratio in females, and high CarE activity in males) should be also taken into account in bean weevil management. Further studies are needed to fully elucidate mechanisms of thymol toxicity and tolerance.

\section{DATA AVAILABILITY STATEMENT}

The raw data supporting the conclusions of this article will be made available by the authors, without undue reservation.

\section{AUTHOR CONTRIBUTIONS}

JL, IK, and DŠJ designed the experiment. JL, DŠJ, and SJ conducted the experiment. AV and SMJ determined enzyme activities. DŠJ and MK performed statistical analysis. JL, DŠJ, and IK prepared the manuscript. All authors have read and agreed to the published version of the manuscript.

\section{FUNDING}

This research was funded by the Ministry of Education, Science and Technological Development of the Republic of Serbia, grant no. 451-03-9/2021-14/200007.

Ataide, J. O., Holtz, F. G., Destefani, F., Deolindo, A. H., Zago, H. B., Menini, L., et al. (2020). Exposure to major components of essential oils and their mixtures cause mortality, sublethal effect and behavioral disturbance of Sitophilus zeamais (Motschulsky) (Coleoptera: Curculionidae). J. Pharmacogn. Phytochem. 9, 1329-1335. doi: 10.22271/phyto.2020.v9.i2v.1 1038

Attia, M. A., Wahba, T. F., Mackled, M. I., and Shawir, M. S. (2017). Resistance status and associated resistance mechanisms to certain insecticides in rice weevil Sitophilus oryzae (Coleoptera: Curculionidae). Alexandria J. Agricult. Sci. 62, 331-340. doi: 10.21608/alexja.2017.6 7624

Austgulen, L. T., Solheim, E., and Scheline, R. R. (1987). Metabolism in rats of p-cymene derivatives: carvacrol and thymol. Pharmacol. Toxicol. 61, 98-102. doi: 10.1111/j.1600-0773.1987.tb01783.x

Barbosa, D. R. S., de Oliveira, J. V., da Silva, P. H. S., Santana, M. F., Breda, M. O., de França, S. M., et al. (2021). Lethal and sublethal effects of chemical constituents from essential oils on Callosobruchus maculatus (F.) (Coleoptera: Chrysomelidae: Bruchinae) in cowpea stored grains. J. Plant Dis. Prot. 128, 1575-1586. doi: 10.1007/s41348-021-00543-x

Boncristiani, H., Underwood, R., Schwarz, R., Evans, J. D., and Pettis, J. (2012). Direct effect of acaricides on pathogen loads and gene expression levels in honey bees Apis mellifera. J. Insect Physiol. 58, 613-620. doi: 10.1016/j.jinsphys.2011. 12.011

Bradford, M. M. (1976). A rapid and sensitive method for the quantitation of microgram quantities of protein utilizing the principle of protein-dye binding. Anal. Biochem. 72, 248-254. doi: 10.1016/j.jinsphys.2011.12.011

Brari, J., and Thakur, D. R. (2015). Fumigant toxicity and cytotoxicity evaluation of monoterpenes against four stored products pests. Int. J. Dev. Res. 5, 5661-5667. 
Brogdon, W. G., McAllister, J. C., and Vulule, J. (1997). Heme peroxidase activity measured in single mosquitoes identifies individuals expressing an elevated oxidase for insecticide resistance. J. Am. Mosq. Control Assoc. 13, 233-237.

Charpentier, A., and Fournier, D. (2001). Levels of total acetylcholinesterase in Drosophila melanogaster in relation to insecticide resistance. Pestic. Biochem. Physiol. 70, 100-107. doi: 10.1006/pest.2001.2549

Charpentier, G., Vidau, C., Ferdy, J. B., Tabart, J., and Vetillard, A. (2014). Lethal and sub-lethal effects of thymol on honeybee (Apis mellifera) larvae reared in vitro. Pest Manag. Sci. 70, 140-147. doi: 10.1002/ps.3539

Chaudhari, A. K., Singh, V. K., Kedia, A., Das, S., and Dubey, N. K. (2021). Essential oils and their bioactive compounds as eco-friendly novel green pesticides for management of storage insect pests: prospects and retrospects. Environ. Sci. Pollut. Res. 28, 18918-18940. doi: 10.1007/s11356-021-12841-w

Chen, Y. Z., Zhang, B. W., Yang, J., Zou, C. S., Li, T., Zhang, G. C., et al. (2021). Detoxification, antioxidant, and digestive enzyme activities and gene expression analysis of Lymantria dispar larvae under carvacrol. J. Asia-Pac. Entomol. 24, 208-216. doi: 10.1016/j.aspen.2020.12.014

Claiborne, A. (1984). "Catalase activity," in Handbook of Methods for Oxygen Radical Research, ed. R. A. Greenwald (Boca Raton, FL: CRC Press), 283-284. doi: 10.1201/9781351072922

Cohen, S. M., Eisenbrand, G., Fukushima, S., Gooderham, N. J., Guengerich, F. P., Hecht, S. S., et al. (2021). FEMA GRAS assessment of natural flavor complexes: origanum oil, thyme oil and related phenol derivative-containing flavoring ingredients. Food Chem. Toxicol. 155:112378. doi: 10.1016/j.fct.2021.112378

da Camara, C. A., Doboszewski, B., de Melo, J. P., Nazarenko, A. Y., dos Santosa, R. B., and Moraesa, M. M. (2022). Novel insecticides from alkylated and acylated derivatives of thymol and eugenol for the control of Plutella xylostella (Lepidoptera: Plutellidae). J. Braz. Chem. Soc. 33, 196-204. doi: 10.21577/01035053.20210137

da Cunha, F. A. B., Wallau, G. L., Pinho, A. I., Nunes, M. E. M., Leite, N. F., Tintino, S. R., et al. (2015). Eugenia uniflora leaves essential oil induces toxicity in Drosophila melanogaster: involvement of oxidative stress mechanisms. Toxicol. Res. 4, 634-644. doi: 10.1039/c4tx00162a

Daglish, G. J., Nayak, M. K., Arthur, F. H., and Athanassiou, C. G. (2018). "Insect pest management in stored grain," in Recent Advances in Stored Product Protection, eds C. G. Athanassiou and F. H. Arthur (Berlin: Springer), 45-63. doi: 10.1007/978-3-662-56125-6_3

Dar, M. A., Kaushik, G., and Chiu, J. F. V. (2020). "Pollution status and biodegradation of organophosphate pesticides in the environment," in Abatement of Environmental Pollutants, eds P. Singh, A. Kumar, and A. Borthakur (Amsterdam: Elsevier), 25-66. doi: 10.1016/B978-0-12-818095-2. 00002-3

de Alvarenga, J. F. R., Genaro, B., Costa, B. L., Purgatto, E., Manach, C., and Fiamoncini, J. (2021). Monoterpenes: current knowledge on food source, metabolism, and health effects. Crit. Rev. Food Sci. Nutr. 2, 1-38. doi: 10.1080/ 10408398.2021.1963945

de Andrade Brito, F., Bacci, L., da Silva Santana, A., da Silva, J. E., de Castro Nizio, D. A., de Lima Nogueira, P. C., et al. (2021). Toxicity and behavioral alterations caused by essential oils of Croton tetradenius and their major compounds on Acromyrmex balzani. Crop. Prot. 137:105259. doi: 10.1016/j.cropro.2020. 105259

de Jong, R. J., Miller, L. M., Molina-Cruz, A., Gupta, L., Kumar, S., and BarillasMury, C. (2007). Reactive oxygen species detoxification by catalase is a major determinant of fecundity in the mosquito Anopheles gambiae. Proc. Natl. Acad. Sci. U.S.A. 104, 2121-2126. doi: 10.1073/pnas.0608407104

de Lame, F. M., Hong, J. J., Shearer, P. W., and Brattsten, L. B. (2001). Sexrelated differences in the tolerance of Oriental fruit moth (Grapholita molesta) to organophosphate insecticides. Pest. Manage. Sci. 57, 827-832. doi: 10.1002/ ps.368

de Melo, C. R., Picanco, M. C., Santos, A. A., Santos, I. B., Pimentel, M. F., Santos, A. C., et al. (2018). Toxicity of essential oils of Lippia gracilis chemotypes and their major compounds on Diaphania hyalinata and non-target species. Crop Prot. 104, 47-51. doi: 10.1016/j.cropro.2017.10.013

de Souza, A. M., Campos, I. M., de Brito, D. D. M. C., Cardoso, C. M., Pontes, E. G., and de Souza, M. A. A. (2019). Efficacy of lemongrass essential oil and citral in controlling Callosobruchus maculatus (Coleoptera: Chrysomelidae), a post-harvest cowpea insect pest. Crop Prot. 119, 191-196. doi: 10.1016/j.cropro. 2019.02.007
Diaz-Albiter, H., Mitford, R., Genta, F. A., Sant'Anna, M. R., and Dillon, R. J. (2011). Reactive oxygen species scavenging by catalase is important for female Lutzomyia longipalpis fecundity and mortality. PLoS One 6:e17486. doi: 10. 1371/journal.pone.0017486

Ebadollahi, A., and Sendi, J. J. (2015). A review on recent research results on bioeffects of plant essential oils against major Coleopteran insect pests. Toxin Rev. 34, 76-91. doi: 10.3109/15569543.2015.1023956

Ellman, G. L., Courtney, K. D., Andres, V. Jr., and Featherstone, R. M. (1961). A new and rapid colorimetric determination of acetylcholinesterase activity. Biochem. Pharmacol. 7, 88-95. doi: 10.1016/0006-2952(61)90145-9

EPA Code 080402 (2021). Available online at: https://www3.epa.gov/pesticides/ chem_search/reg_actions/registration/decision_PC-080402_23-Mar-06.pdf (accessed December 22, 2021).

Escobar, C. A. M., Pérez, M. C., Romanelli, G. P., and Blustein, G. (2020). Thymol bioactivity: a review focusing on practical applications. Arab. J. Chem. 13, 9243-9269. doi: 10.1016/j.arabjc.2020.11.009

Feyereisen, R. (2012). "Insect CYP genes and P450 enzymes ", in Insect Molecular Biology and Biochemistry, ed. L. I. Gilbert (Cambridge, MA: Academic Press), 236-316. doi: 10.1016/B978-0-12-384747-8.10008-X

Finney, D. J. (1971). Probit Analysis, 3th Edn. Cambridge: Cambridge University Press. doi: 10.1002/jps.2600600940

Floros, G. D., Kokkari, A. I., Kouloussis, N. A., Kantiranis, N. A., Damos, P., Filippidis, A. A., et al. (2018). Evaluation of the natural zeolite lethal effects on adults of the bean weevil under different temperatures and relative humidity regimes. J. Econ. Entomol. 111, 482-490. doi: 10.1093/jee/tox305

Fouad, E. A., and Abotaleb, A. O. (2021). Sublethal effects of two insecticides, deltamethrin, thiamethoxam and the botanical insecticide (Foeniculum vulgare Mill.) on Callosobruchus maculates (Fabr.) (Coleoptera: Bruchidae). Egypt. Acad. J. Biol. Sci. A Entomol. 14, 255-269. doi: 10.21608/EAJBSA.2021.1 61753

Freitas, R. S., Faroni, L. R. A., and Sousa, A. H. (2016). Hermetic storage for control of common bean weevil, Acanthoscelides obtectus (Say). J. Stored Prod. Res. 66, 1-5. doi: 10.1016/j.jspr.2015.12.004

Fuentes-Contreras, E., Reyes, M., Barros, W., and Sauphanor, B. (2007). Evaluation of azinphos-methyl resistance and activity of detoxifying enzymes in codling moth (Lepidoptera: Tortricidae) from central Chile. J. Econ. Entomol. 100, 551-556. doi: 10.1093/jee/100.2.551

Gaire, S., Zheng, W., Scharf, M. E., and Gondhalekar, A. D. (2021). Plant essential oil constituents enhance deltamethrin toxicity in a resistant population of bed bugs (Cimexlectularius L.) by inhibiting cytochrome P450 enzymes. Pestic. Biochem. Phys. 175:104829. doi: 10.1016/j.pestbp.2021.104829

Gao, S., Zhang, K., Wei, L., Wei, G., Xiong, W., Lu, Y., et al. (2020). Insecticidal activity of Artemisia vulgaris essential oil and transcriptome analysis of Tribolium castaneum in response to oil exposure. Front. Genet. 11:589. doi: 10.3389/fgene. 2020.00589

Gołebiowski, M., Malinski, E., Nawrot, J., and Stepnowski, P. (2008). Identification andcharacterization of surface lipid components of the dried-bean beetle Acanthoscelides obtectus (Say) (Coleoptera: Bruchidae). J. Stored Prod. Res. 44, 386-388. doi: 10.1016/j.jspr.2008.02.010

Govindarajan, M., Sivakumar, R., Rajeswary, M., and Veerakumar, K. (2013). Mosquito larvicidal activity of thymol from essential oil of Coleus aromaticus Benth. against Culex tritaeniorhynchus, Aedes albopictus, and Anopheles subpictus (Diptera: Culicidae). Parasitol. Res. 112, 3713-3721. doi: 10.1007/ s00436-013-3557-2

Guedes, R. N. C., Walse, S. S., and Throne, J. E. (2017). Sublethal exposure, insecticide resistance, and community stress. Curr. Opin. Insect Sci. 21, 47-53. doi: 10.1016/j.cois.2017.04.010

Habig, W. H., Pabst, M. J., and Jakoby, W. B. (1974). Glutathione S-transferases. The first enzymatic step in mercapturic acid formation. J. Biol. Chem. 249, 7130-7139. doi: 10.1016/S0021-9258(19)42083-8

Hategekimana, A., and Erler, F. (2020). Fecundity and fertility inhibition effects of some plant essential oils and their major components against Acanthoscelides obtectus Say (Coleoptera: Bruchidae). J. Plant Dis. Prot. 127, 615-623. doi: 10.1007/s41348-020-00311-3

Herrera, J. M., Zunino, M. P., Dambolena, J. S., Pizzolitto, R. P., Gañan, N. A., Lucini, E. I., et al. (2015). Terpene ketones as natural insecticides against Sitophilus zeamais. Ind. Crops Prod. 70, 435-442. doi: 10.1016/j.indcrop.2015. 03.074 
Hieu, T. T., Kim, S. I., and Ahn, Y. J. (2014). Toxicity of Zanthoxylum piperitum and Zanthoxylum armatum oil constituents and related compounds to Stomoxys calcitrans (Diptera: Muscidae). J. Med. Entomol. 49, 1084-1091. doi: 10.1603/ ME12047

Hu, J., Wang, W., Dai, J., and Zhu, L. (2019). Chemical composition and biological activity against Tribolium castaneum (Coleoptera: Tenebrionidae) of Artemisia brachyloba essential oil. Ind. Crops Prod. 128, 29-37. doi: 10.1016/j.indcrop. 2018.10.076

Huang, Y., Liao, M., Yang, Q., Xiao, J., Hu, Z., Zhou, L., et al. (2018). Transcriptome profiling reveals differential gene expression of detoxification enzymes in Sitophilus zeamais responding to terpinen-4-ol fumigation. Pestic. Biochem. Physiol. 149, 44-53. doi: 10.1016/j.pestbp.2018.05.008

Hummelbrunner, L. A., and Isman, M. B. (2001). Acute, sublethal, antifeedant, and synergistic effects of monoterpenoid essential oil compounds on the tobacco cutworm, Spodoptera litura (Lep., Noctuidae). J. Agric. Food Chem. 49, 715-720. doi: 10.1021/jf000749t

Hwang, C. E., Kim, Y. H., Kwon, D. H., Seong, K. M., Choi, J. Y., Je, Y. H., et al. (2014). Biochemical and toxicological properties of two acetylcholinesterases from the common bed bug, Cimex lectularius. Pestic. Biochem. Physiol. 110, 20-26. doi: 10.1016/j.pestbp.2014.02.002

Ismail, S. (2021). Synergistic efficacy of plant essential oils with cypermethrin and chlorpyrifos against Spodoptera littoralis, field populations in Egypt. Int. J. Adv. Biol. Biomed. Res. 9, 128-137. doi: 10.22034/ijabbr.2021.239417

Isman, M. B. (2020). Bioinsecticides based on plant essential oils: a short overview. Z. Naturforsch. C 75, 179-182. doi: 10.1515/znc-2020-0038

Iturralde-García, R. D., Castañé, C., Wong-Corral, F. J., and Riudavets, J. (2020). Biological control of Acanthoscelides obtectus and Zabrotes subfasciatus in stored dried beans. Bio. Control 65, 693-701. doi: 10.1007/s10526-020-10048-5

Jang, M., Kim, J., Yoon, K. A., Lee, S. H., and Park, C. G. (2017). Biological activity of Myrtaceae plant essential oils and their major components against Drosophila suzukii (Diptera: Drosophilidae). Pest Manag. Sci. 73, 404-409. doi: $10.1002 / p s .4430$

Jankowska, M., Rogalska, J., Wyszkowska, J., and Stankiewicz, M. (2018). Molecular targets for components of essential oils in the insect nervous system a review. Molecules 23:34. doi: 10.3390/molecules23010034

Jevremović, S., Lazarević, J., Kostić, M., Krnjajić, S., Ugrenović, V., Radonjić, A., et al. (2019). Contact application of Lamiaceae botanicals reduces bean weevil infestation in stored beans. Arch. Biol. Sci. 71, 665-676. doi: 10.2298/ ABS190617049J

Johnson, C. D. (1981). "Relations of Acanthoscelides with their plant hosts," in The Ecology of Bruchids Attacking Legumes (Pulses), ed. V. Labeyrie (Dordrecht: Springer), 73-81. doi: 10.1007/978-94-017-3286-4_7

Kanda, D., Kaur, S., and Koul, O. (2017). A comparative study of monoterpenoids and phenylpropanoids from essential oils against stored grain insects: acute toxins or feeding deterrents. J. Pest Sci. 90, 531-545. doi: 10.1007/s10340-0160800-5

Keszthelyi, S., Bosnyakne, E. H., Horváth, D., Csóka, Á, Kovacs, G., and Tamas, D. (2018). Nutrient content restructuring and CT-measured density, volume attritions on damaged beans caused by Acanthoscelides obtectus Say (Coleoptera: Chrysomelidae). J. Plant Prot. Res. 58, 91-95. doi: 10.24425/11 9123

Kim, S. I., Ahn, Y. J., and Kwon, H. W. (2012). "Toxicity of aromatic plants and their constituents against coleopteran stored products insect pests," in New Perspectives in Plant Protection, ed. A. R. Bandani (London: InTech), 93-120. doi: 10.5772/36288_5

Kim, S. I., Yoon, J. S., Jung, J. W., Hong, K. B., Ahn, Y. J., and Kwon, H. W. (2010). Toxicity and repellency of origanum essential oil and its components against Tribolium castaneum (Coleoptera: Tenebrionidae) adults. J. Asia-Pac. Entomol. 13, 369-373. doi: 10.1016/j.aspen.2010.06.011

Kim, Y. H., and Lee, S. H. (2018). Invertebrate acetylcholinesterases: insights into their evolution and non-classical functions. J. Asia-Pac. Entomol. 21, 186-195. doi: 10.1016/j.aspen.2017.11.017

Kim, Y. H., Cha, D. J., Jung, J. W., Kwon, H. W., and Lee, S. H. (2012). Molecular and kinetic properties of two acetylcholinesterases from the western honey bee, Apis mellifera. PLoS One 7:e48838. doi: 10.1371/journal.pone.004 8838

Kim, Y. H., Kwon, D. H., Ahn, H. M., Koh, Y. H., and Lee, S. H. (2014). Induction of soluble AChE expression via alternative splicing by chemical stress in Drosophila melanogaster. Insect Biochem. Mol. Biol. 48, 75-82. doi: 10.1016/j. ibmb.2014.03.001

Kiran, S., and Prakash, B. (2015a). Assessment of toxicity, antifeedant activity, and biochemical responses in stored-grain insects exposed to lethal and sublethal doses of Gaultheria procumbens L. essential oil. J. Agric. Food Chem. 63, 10518-10524. doi: 10.1021/acs.jafc.5b03797

Kiran, S., and Prakash, B. (2015b). Toxicity and biochemical efficacy of chemically characterized Rosmarinus officinalis essential oil against Sitophilus oryzae and Oryzaephilus surinamensis. Ind. Crops Prod. 74, 817-823. doi: 10.1016/j. indcrop.2015.05.073

Kiran, S., Kujur, A., Patel, L., Ramalakshmi, K., and Prakash, B. (2017). Assessment of toxicity and biochemical mechanisms underlying the insecticidal activity of chemically characterized Boswellia carterii essential oil against insect pest of legume seeds. Pestic. Biochem. Phys. 139, 17-23. doi: 10.1016/j.pestbp.2017.04. 004

Kısa, A., Akyüz, M., Çoğun, H. Y., Kordali, Ş, Bozhüyük, A. U., Tezel, B., et al. (2018). Effects of Olea europaea L. leaf metabolites on the tilapia (Oreochromis niloticus) and three stored pests, Sitophilus granarius, Tribolium confusum and Acanthoscelides obtectus. Rec. Nat. Prod. 12, 201-215. doi: 10.25135/rnp.23.17. 07.126

Koul, O., Singh, R., Kaur, B., and Kanda, D. (2013). Comparative study on the behavioral response and acute toxicity of some essential oil compounds and their binary mixtures to larvae of Helicoverpa armigera, Spodoptera litura and Chilo partellus. Ind. Crops Prod. 49, 428-436. doi: 10.1007/s10340-018-01075-4

Kumrungsee, N., Pluempanupat, W., Koul, O., and Bullangpoti, V. (2014). Toxicity of essential oil compounds against diamondback moth, Plutella xylostella, and their impact on detoxification enzyme activities. J. Pest Sci. 87, 721-729. doi: 10.1007/s10340-014-0602-6

Labeyrie, V. (1990). "The bean beetle (Acanthoscelides obtectus) and its host, the French bean (Phaseolus vulgaris): a two-way colonization story," in Biological Invasions in Europe and the Mediterranean Basin, eds F. di Castri, A. J. Hansen, and M. Debussche (Dordrecht: Springer), 229-243. doi: 10.1007/s10340-0140602-6

Lazarević, J., Đordević, M., Stojković, B., and Tucić, N. (2013). Resistance to prooxidant agent paraquat in the short-and long-lived lines of the seed beetle (Acanthoscelides obtectus). Biogerontology 14, 141-152. doi: 10.1007/s10522013-9417-8

Lazarević, J., Jevremović, S., Kostić, I., Kostić, M., Vuleta, A., Manitašević Jovanović, S., et al. (2020). Toxic, oviposition deterrent and oxidative stress effects of Thymus vulgaris essential oil against Acanthoscelides obtectus. Insects 11:563. doi: 10.3390/insects 11090563

Lazarević, J., Radojković, A., Kostić, I., Krnjajić, S., Mitrović, J., Kostić, M. B., et al. (2018). Insecticidal impact of alumina powders against Acanthoscelides obtectus (Say). J. Stored Prod. Res. 77, 45-54. doi: 10.1016/j.jspr.2018.02.006

Lazarević, J., Tucić, N., Šešlija Jovanović, D., Veèeøa, J., and Kodrík, D. (2012). The effects of selection for early and late reproduction on metabolite pools in Acanthoscelides obtectus Say. Insect Sci. 19, 303-314. doi: 10.1111/j.1744-7917. 2011.01457.x

Le Goff, G., Hilliou, F., Siegfried, B. D., Boundy, S., Wajnberg, E., Sofer, L., et al. (2006). Xenobiotic response in Drosophila melanogaster: sex dependence of P450 and GST gene induction. Insect Biochem. Mol. Biol. 36, 674-682. doi: 10.1016/j.ibmb.2006.05.009

Lee, E. J., Kim, J. R., Choi, D. R., and Ahn, Y. J. (2008). Toxicity of cassia and cinnamon oil compounds and cinnamaldehyde-related compounds to Sitophilus oryzae (Coleoptera: Curculionidae). J. Econ. Entomol. 101, 19601966. doi: 10.1603/0022-0493-101.6.1960

Lee, S. H., Kim, Y. H., Kwon, D. H., Cha, D. J., and Kim, J. H. (2015). Mutation and duplication of arthropod acetylcholinesterase: implications for pesticide resistance and tolerance. Pestic. Biochem. Physiol. 120, 118-124. doi: 10.1016/ j.pestbp.2014.11.004

Leroi, B. (1981). "Feeding, longevity and reproduction of adults of Acanthoscelides obtectus Say in laboratory conditions," in The Ecology of Bruchids Attacking Legumes (Pulses), (Dordrecht: Springer), 101-111. doi: 10.1007/978-94-0173286-4_10

Liao, M., Xiao, J. J., Zhou, L. J., Liu, Y., Wu, X. W., Hua, R. M., et al. (2016). Insecticidal activity of Melaleuca alternifolia essential oil and RNA-Seq analysis of Sitophilus zeamais transcriptome in response to oil fumigation. PLoS One 11:e0167748. doi: 10.1371/journal.pone.0167748 
Liao, M., Xiao, J. J., Zhou, L. J., Yao, X., Tang, F., Hua, R. M., et al. (2017). Chemical composition, insecticidal and biochemical effects of Melaleuca alternifolia essential oil on the Helicoverpa armigera. J. Appl. Entomol. 141, 721-728. doi: 10.1111/jen.12397

Liao, M., Yang, Q. Q., Xiao, J. J., Huang, Y., Zhou, L. J., Hua, R. M., et al. (2018). Toxicity of Melaleuca alternifolia essential oil to the mitochondrion and NAD+/NADH dehydrogenase in Tribolium confusum. Peer J. 6:e5693. doi: $10.7717 /$ peerj. 5693

Lima, A. P., Santana, E. D., Santos, A. C., Silva, J. E., Ribeiro, G. T., Pinheiro, A. M., et al. (2020). Insecticide activity of botanical compounds against Spodoptera frugiperda and selectivity to the predatory bug Podisus nigrispinus. Crop Prot. 136:105230. doi: 10.1016/j.cropro.2020.105230

Liu, H., Lei, X., Du, L., Yin, J., Shi, H., Zhang, T., et al. (2019). Antennaespecific carboxylesterase genes from Indian meal moth: identification, tissue distribution and the response to semiochemicals. J. Stored Prod. Res. 84:101528. doi: 10.1016/j.jspr.2019.101528

Liu, J., Hua, J., Qu, B., Guo, X., Wang, Y., Shao, M., et al. (2021). Insecticidal terpenes from the essential oils of Artemisia nakaii and their inhibitory effects on acetylcholinesterase. Front. Plant Sci. 12:720816. doi: 10.3389/fpls.2021. 720816

López, M. D., and Pascual-Villalobos, M. J. (2010). Mode of inhibition of acetylcholinesterase by monoterpenoids and implications for pest control. Ind. Crops Prod. 31, 284-288. doi: 10.1016/j.indcrop.2009.11.005

López, M. D., and Pascual-Villalobos, M. J. (2015). Are monoterpenoids and phenylpropanoids efficient inhibitors of acetylcholinesterase from stored product insect strains? Flavour Frag. J. 30, 108-112. doi: 10.1002/ffj.3220

López, S., Domínguez, A., Guerrero, Á, and Quero, C. (2021). Inhibitory effect of thymol on pheromone-mediated attraction in two pest moth species. Sci. Rep. 11, 1-10. doi: 10.1038/s41598-020-79550-1

Lu, Y., Park, Y., Gao, X., Zhang, X., Yao, J., Pang, Y. P., et al. (2012). Cholinergic and non-cholinergic functions of two acetylcholinesterase genes revealed by gene-silencing in Tribolium castaneum. Sci. Rep. 2, 1-7. doi: 10.1038/srep00288

Mancini, E., Senatore, F., Del Monte, D., De Martino, L., Grulova, D., Scognamiglio, M., et al. (2015). Studies on chemical composition, antimicrobial and antioxidant activities of five Thymus vulgaris L. essential oils. Molecules 20, 12016-12028. doi: 10.3390/molecules200712016

Manna, B., Maiti, S., and Das, A. (2020). Bioindicator potential of Spathosternum prasiniferum prasiniferum (Orthoptera; Acridoidea) in pesticide (azadirachtin)induced radical toxicity in gonadal/nymphal tissues; correlation with ecosustainability. J. Asia Pac. Entomol. 23, 350-357. doi: 10.1016/j.aspen.2020.02. 007

Mikhailov, A. T., and Torrado, M. (1999). Carboxylesterase overexpression in the male reproductive tract: a universal safeguarding mechanism? Reprod. Fertil. Dev. 11, 133-146. doi: 10.1071/RD99011

Mikhailov, A. T., and Torrado, M. (2000). Carboxylesterases moonlight in the male reproductive tract: a functional shift pivotal for male fertility. Front. Biosci. 5:e53-e62. doi: 10.2741/mikhail

Misra, H. P., and Fridovich, I. (1972). The role of superoxide anion in the autoxidation of epinephrine and simple assay for superoxide dismutase. J. Biol. Chem. 247, 3170-3175. doi: 10.1016/S0021-9258(19)45228-9

Mohapatra, D., Kar, A., and Giri, S. K. (2015). Insect pest management in stored pulses: an overview. Food Bioproc. Tech. 8, 239-265. doi: 10.1007/s11947-0141399-2

Mojarab-Mahboubkar, M., Sendi, J. J., and Aliakbar, A. (2015). Effect of Artemisia annua L. essential oil on toxicity, enzyme activities, and energy reserves of cotton bollworm Helicoverpa armigera (Hübner) (Lepidoptera: Noctuidae). J. Plant Prot. Res. 55:49. doi: 10.1515/jppr-2015-0049

Montella, I. R., Schama, R., and Valle, D. (2012). The classification of esterases: an important gene family involved in insecticide resistance-A review. Mem. Inst. Oswaldo Cruz. 107, 437-449. doi: 10.1590/s0074-02762012000400001

Navarro-Roldán, M. A., Avilla, J., Bosch, D., Valls, J., and Gemeno, C. (2017). Comparative effect of three neurotoxic insecticides with different modes of action on adult males and females of three tortricid moth pests. J. Econom. Entomol. 110, 1740-1749. doi: 10.1093/jee/tox113

Navarro-Roldán, M. A., Bosch, D., Gemeno, C., and Siegwart, M. (2020). Enzymatic detoxification strategies for neurotoxic insecticides in adults of three tortricid pests. Bull. Entomol. Res. 110, 144-154. doi: 10.1017/ S0007485319000415
Nayak, M. K., and Daglish, G. J. (2018). “Importance of stored product insects," in Recent Advances in Stored Product Protection, eds G. Athanassiou and F. H. Arthur (Berlin: Springer), 1-17. doi: 10.1007/978-3-662-56125-6_1

Nerio, L. S., Oliver-Verbal, J., and Stashenko, E. (2010). Repellent activity of essential oils: a review. Bioresour. Technol. 101,372-378. doi: 10.1016/j.biortech. 2009.07.048

Norris, E. J., Bartholomay, L., and Coats, J. (2018). "Present and future outlook: the potential of green chemistry in vector control," in Advances in the Biorational Control of Medical and Veterinary Pests, eds E. J. Norris, J. R. Coats, A. D. Gross, and J. M. Clark (Washington, DC: ACS), 43-62. doi: 10.1021/bk-2018-1289. ch004

Obeng-Ofori, D. (2010). "Residual insecticides, inert dusts and botanicals for the protection of durable stored products against pest infestation in developing countries," in Proceedings of the Sixth International Working Conference on Stored-product Protection, eds M. O. Carvalho, P. G. Fields, C. S. Adler, F. H. Arthur, C. G. Athanassiou, J. F. Campbell, et al. (Estoril: Julius-Kühn-Archiv), 774-788. doi: 10.5073/jka.2010.425.141

Oliveira, A. P., Santana, A. S., Santana, E. D., Lima, A. P. S., Faro, R. R., Nunes, R. S., et al. (2017). Nanoformulation prototype of the essential oil of Lippia sidoides and thymol to population management of Sitophilus zeamais (Coleoptera: Curculionidae). Ind. Crops Prod. 107, 198-205. doi: 10.1016/j.indcrop.2017.05. 046

Oliveira, A. P., Santos, A. A., Santana, A. S., Lima, A. P. S., Melo, C. R., Santana, E. D., et al. (2018). Essential oil of Lippia sidoides and its major compound thymol: toxicity and walking response of populations of Sitophilus zeamais (Coleoptera: Curculionidae). Crop Prot. 112, 33-38. doi: 10.1016/j.cropro.2018. 05.011

Oni, M. O., Ogungbite, O. C., Oguntuase, S. O., Bamidele, O. S., and Ofuya, T. I. (2019). Inhibitory effects of oil extract of green Acalypha (Acalypha wilkesiana) on antioxidant and neurotransmitter enzymes in Callosobruchus maculatus. J. Basic Appl. Zool. 80, 1-13. doi: 10.1186/s41936-019-0116-0

Panini, M., Manicardi, G. C., Moores, G. D., and Mazzoni, E. (2016). An overview of the main pathways of metabolic resistance in insects. Invertebr. Surviv. J. 13, 326-335. doi: 10.25431/1824-307X/isj.v13i1.326-335

Papachristos, D. P., and Stamopoulos, D. C. (2002). Repellent, toxic and reproduction inhibitory effects of essential oil vapours on Acanthoscelides obtectus (Say) (Coleoptera: Bruchidae). J. Stored Prod. Res. 38, 117-128. doi: 10.1016/S0022-474X(01)00007-8

Papachristos, D. P., Karamanoli, K. I, Stamopoulos, D. C., and MenkissogluSpiroudi, U. (2004). The relationship between the chemical composition of three essential oils and their insecticidal activity against Acanthoscelides obtectus (Say). Pest Manag. Sci. 60, 514-520. doi: 10.1002/ps.798

Park, C. G., Jang, M., Yoon, K. A., and Kim, J. (2016). Insecticidal and acetylcholinesterase inhibitory activities of Lamiaceae plant essential oils and their major components against Drosophila suzukii (Diptera: Drosophilidae). Ind. Crops Prod. 89, 507-513. doi: 10.1016/j.indcrop.2016.06.008

Park, J. H., Jeon, Y. J., Lee, C. H., Chung, N., and Lee, H. S. (2017). Insecticidal toxicities of carvacrol and thymol derived from Thymus vulgaris Lin. against Pochazia shantungensis Chou \& Lu., newly recorded pest. Sci. Rep. 7, 1-7. doi: $10.1038 /$ srep40902

Passreiter, C. M., Wilson, J., Andersen, R., and Isman, M. B. (2004). Metabolism of thymol and trans-anethole in larvae of Spodoptera litura and Trichoplusia ni (Lepidoptera: Noctuidae). J. Agri. Food Chem. 52, 2549-2551. doi: 10.1021/ jf035386m

Pavela, R. (2011a). Antifeedant and larvicidal effects of some phenolic components of essential oils lasp lines of introduction against Spodoptera littoralis (Boisd.). J. Essent. Oil Bear. Plants 14, 266-273. doi: 10.1080/0972060X.2011.1064 3932

Pavela, R. (2011b). Insecticidal properties of phenols on Culex quinquefasciatus Say and Musca domestica L. Parasitol. Res. 109, 1547-1553. doi: 10.1007/s00436011-2395-3

Pavela, R. (2016). History, presence and perspective of using plant extracts as commercial botanical insecticides and farm products for protection against insects-a review. Plant Prot. Sci. 52, 229-241. doi: 10.17221/31/2016-PPS

Pavela, R., Maggi, F., Mazzara, E., Torresi, J., Cianfaglione, K., Benelli, G., et al. (2021). Prolonged sublethal effects of essential oils from non-wood parts of nine conifers on key insect pests and vectors. Ind. Crops Prod. 168:113590. doi: 10.1016/j.indcrop.2021.113590 
Pavela, R., Morshedloo, M. R., Mumivand, H., Khorsand, G. J., Karami, A., Maggi, F., et al. (2020). Phenolic monoterpene-rich essential oils from Apiaceae and Lamiaceae species: insecticidal activity and safety evaluation on non-target earthworms. Entomol. Gen. 40, 421-435. doi: 10.1127/entomologia/2020/1131

Peter, K. V., and Shylaja, M. R. (2012). "Introduction to herbs and spices: definitions, trade and applications," in Handbook of Herbs and Spices, ed. K. V. Peter (Cambridge: Woodhead Publishing), 1-24. doi: 10.1533/9780857095 671.1

Petrović, M., Popović, A., Kojić, D., Šućur, J., Bursić, V., Aćimović, M., et al. (2019). Assessment of toxicity and biochemical response of Tenebrio molitor and Tribolium confusum exposed to Carum carvi essential oil. Entomol. Gen. 38, 333-348. doi: 10.1127/entomologia/2019/0697

Pinho, A. I., Wallau, G. L., Nunes, M. E. M., Leite, N. F., Tintino, S. R., da Cruz, L. C., et al. (2014). Fumigant activity of the Psidium guajava var. pomifera (Myrtaceae) essential oil in Drosophila melanogaster by means of oxidative stress. Oxid. Med. Cell. Longev. 4:696785. doi: 10.1155/2014/696785

Piri, A., Sahebzadeh, N., Zibaee, A., Sendi, J. J., Shamakhi, L., and Shahriari, M. (2020). Toxicity and physiological effects of ajwain (Carum copticum, Apiaceae) essential oil and its major constituents against Tuta absoluta (Meyrick) (Lepidoptera: Gelechiidae). Chemosphere 256:127103. doi: 10.1016/ j.chemosphere.2020.127103

Pletcher, S. D. (1999). Model fitting and hypothesis testing for age-specific mortality data. J. Evol. Biol. 12, 430-439. doi: 10.1046/j.1420-9101.1999.00058.x

Prasantha, B. R., Reichmuth, C. H., and Adler, C. (2019). Lethality and kinetic of diatomaceous earth uptake by the bean weevil (Acanthoscelides obtectus [Say] Coleoptera: Bruchinae): Influence of short-term exposure period. J. Stored Prod. Res. 84:101509. doi: 10.1016/j.jspr.2019.101509

Rajendran, S. (2020). Insect pest management in stored products. Outlooks Pest Manag. 31, 24-35. doi: 10.1564/v31_feb_05

Rajkumar, V., Gunasekaran, C., Christy, I. K., Dharmaraj, J., Chinnaraj, P., and Paul, C. A. (2019). Toxicity, antifeedant and biochemical efficacy of Mentha piperita L. essential oil and their major constituents against stored grain pest. Pestic. Biochem. Physiol. 156, 138-144. doi: 10.1016/j.pestbp.2019.02.016

Rattan, R. S. (2010). Mechanism of action of insecticidal secondary metabolites of plant origin. Crop Prot. 29, 913-920. doi: 10.1016/j.cropro.2010.05.008

Regnault-Roger, C., and Hamraoui, A. (1995). Fumigant toxic activity and reproductive inhibition induced by monoterpenes on Acanthoscelides obtectus (Say) (Coleoptera), a bruchid of kidney bean (Phaseolus vulgaris L.). J. Stored Prod. Res. 31, 291-299. doi: 10.1016/0022-474X(95)00025-3

Regnault-Roger, C., Hamraoui, A., Holeman, M., Theron, E., and Pinel, R. (1993). Insecticidal effect of essential oils from mediterranean plants upon Acanthoscelides obtectus Say (Coleoptera, Bruchidae), a pest of kidney bean (Phaseolus vulgaris L.). J. Chem. Ecol. 19, 1233-1244. doi: 10.1007/BF00987383

Reynoso, M. M. N., Lucia, A., Zerba, E. N., and Alzogaray, R. A. (2018). Eugenolhyperactivated nymphs of Triatoma infestans become intoxicated faster than non-hyperactivated nymphs when exposed to a permethrin-treated surface. Parasite. Vector. 11, 1-9. doi: 10.1186/s13071-018-3146-4

Robert, J. A., Pitt, C., Bonnett, T. R., Yuen, M. M., Keeling, C. I., Bohlmann, J., et al. (2013). Disentangling detoxification: gene expression analysis of feeding mountain pine beetle illuminates molecular-level host chemical defense detoxification mechanisms. PLoS One 8:e77777. doi: 10.1371/journal.pone. 0077777

Rodríguez-González, Á, Casquero, P. A., Suárez-Villanueva, V., Carro-Huerga, G., Álvarez-García, S., Mayo-Prieto, S., et al. (2018). Effect of trichodiene production by Trichoderma harzianum on Acanthoscelides obtectus. J. Stored Prod. Res. 77, 231-239. doi: 10.1016/j.jspr.2018.05.001

Rodríguez-González, Á, Porteous-Álvarez, A. J., Del Val, M., Casquero, P. A., and Escriche, B. (2020). Toxicity of five Cry proteins against the insect pest Acanthoscelides obtectus (Coleoptera: Chrisomelidae: Bruchinae). J. Invertebr. Pathol. 169:107295. doi: 10.1016/j.jip.2019.107295

Rovenko, B. M., Kubrak, O. I., Gospodaryov, D. V., Perkhulyn, N. V., Yurkevych, I. S., Sanz, A., et al. (2015). High sucrose consumption promotes obesity whereas its low consumption induces oxidative stress in Drosophila melanogaster. J. Insect Physiol. 79, 42-54. doi: 10.1016/j.jinsphys.2015.05.007

Roy, S., and Prasad, A. K. (2018). Sex-based variation in insecticide susceptibility and tolerance related biochemical parameters in tea mosquito bug Helopeltis theivora. Phytoparasitica 46, 405-410. doi: 10.1007/s12600-018-0670-x
Ruiz, M. J., Juárez, M. L., Jofré Barud, F., Goane, L., Valladares, G. A., Bachmann, G. E., et al. (2021). Lemon and Schinus polygama essential oils enhance male mating success of Anastrepha fraterculus. Entomol. Exp. Appl. 169, 172-182. doi: 10.1111/eea.13005

Ruttanaphan, T., Pluempanupat, W., Aungsirisawat, C., Boonyarit, P., Goff, G. L., and Bullangpoti, V. (2019). Effect of plant essential oils and their major constituents on cypermethrin tolerance associated detoxification enzyme activities in Spodoptera litura (Lepidoptera: Noctuidae). J. Econom. Entomol. 112, 2167-2176. doi: 10.1093/jee/toz126

Salim, A. M., Shakeel, M., Ji, J., Kang, T., Zhang, Y., Ali, E., et al. (2017). Cloning, expression, and functional analysis of two acetylcholinesterase genes in Spodoptera litura (Lepidoptera: Noctuidae). Comp. Biochem. Physiol. B: Biochem. Mol. Biol. 206, 16-25. doi: 10.1016/j.cbpb.2017.01.007

Schmale, I., Wäckers, F. L., Cardona, C., and Dorn, S. (2002). Field infestation of Phaseolus vulgaris by Acanthoscelides obtectus (Coleoptera: Bruchidae), parasitoid abundance, and consequences for storage pest control. Environ. Entomol. 31, 859-863. doi: 10.1603/0046-225X-31.5.859

Senthil-Nathan, S. (2020). A review of resistance mechanisms of synthetic insecticides and botanicals, phytochemicals, and essential oils as alternative larvicidal agents against mosquitoes. Front. Physiol. 10:1591. doi: 10.3389/fphys. 2019.01591

Šešlija Jovanović, D., Đorđević, M., Savković, U., and Lazarević, J. (2014). The effect of mitochondrial complex I inhibitor on longevity of short-lived and long-lived seed beetles and its mitonuclear hybrids. Biogerontology 15, 487-501. doi: 10.1007/s10522-014-9520-5

Šešlija, D., Blagojević, D., Spasić, M., and Tucić, N. (1999). Activity of superoxide dismutase and catalase in the bean weevil (Acanthoscelides obtectus) selected for postponed senescence. Exp. Gerontol. 34, 185-195. doi: 10.1016/S05315565(98)00078-3

Shahriari, M., Sahbzadeh, N., Zibaee, A., Khani, A., and Senthil-Nathan, S. (2017). Metabolic response of Ephestia kuehniella Zeller (Lepidoptera: Pyralidae) to essential oil of Ajwain and thymol. Toxin Rev. 36, 204-209. doi: 10.1080/ 15569543.2017.1294605

Shahriari, M., Zibaee, A., Sahebzadeh, N., and Shamakhi, L. (2018). Effects of $\alpha$-pinene, trans-anethole, and thymol as the essential oil constituents on antioxidant system and acetylcholine esterase of Ephestia kuehniella Zeller (Lepidoptera: Pyralidae). Pestic. Biochem. Physiol. 150, 40-47. doi: 10.1016/j. pestbp.2018.06.015

Shang, X. F., Dai, L. X., Liu, Y. Q., Zhao, Z. M., Li, J. C., Yang, G. Z., et al. (2019). Acaricidal activity and enzyme inhibitory activity of active compounds of essential oils against Psoroptes cuniculi. Vet. Parasitol. 267, 54-59. doi: 10. 1016/j.vetpar.2019.01.013

Sharma, S. P., Sharma, M., and Kakkar, R. (1995). Methionine-lnduced Alterations in the Life Span, Antioxidant Enzymes, and Peroxide Levels in Aging Zaprionus paravittiger (Diptera). Gerontology 41, 86-93. doi: 10.1159/00021 3668

Singh, R., Koul, O., Rup, P. J., and Jindal, J. (2009). Toxicity of some essential oil constituents and their binary mixtures against Chilo partellus (Lepidoptera: Pyralidae). Int. J. Trop. Insect Sci. 29, 93-101. doi: 10.1017/S174275840999 0087

Subaharan, K., Senthoorraja, R., Manjunath, S., Thimmegowda, G. G., Pragadheesh, V. S., Bakthavatsalam, N., et al. (2021). Toxicity, behavioural and biochemical effect of Piper betle L. essential oil and its constituents against housefly, Musca domestica L. Pestic. Biochem. Physiol. 174:104804. doi: 10.1016/j.pestbp.2021.104804

Sun, J., Feng, Y., Wang, Y., Li, J., Zou, K., Liu, H., et al. (2020). Investigation of pesticidal effects of Peucedanum terebinthinaceum essential oil on three stored-product insects. Rec. Nat. Prod. 14, 177-189. doi: 10.25135/rnp.149.19. 05.1287

Szczepanik, M., Zawitowska, B., and Szumny, A. (2012). Insecticidal activities of Thymus vulgaris essential oil and its components (thymol and carvacrol) against larvae of lesser mealworm, Alphitobius diaperinus Panzer (Coleoptera: Tenebrionidae). Allelopathy J. 30, 129-142.

Szentesi, Á (2021). How the seed coat affects the mother's oviposition preference and larval performance in the bean beetle (Acanthoscelides obtectus, Coleoptera: Chrysomelidae, Bruchinae) in leguminous species. BMC Ecol. Evol. 21:1-14. doi: 10.1186/s12862-021-01892-9 
Tak, J. H., and Isman, M. B. (2017). Acaricidal and repellent activity of plant essential oil-derived terpenes and the effect of binary mixtures against Tetranychus urticae Koch (Acari: Tetranychidae). Ind. Crops Prod. 108, 786792. doi: 10.1016/j.indcrop.2017.08.003

Tak, J. H., Jovel, E., and Isman, M. B. (2017). Effects of rosemary, thyme and lemongrass oils and their major constituents on detoxifying enzyme activity and insecticidal activity in Trichoplusia ni. Pestic. Biochem. Physiol. 140, 9-16. doi: 10.1016/j.pestbp.2017.01.012

Tasaki, E., Kobayashi, K., Matsuura, K., and Iuchi, Y. (2017). An efficient antioxidant system in a long-lived termite queen. PLoS One 12:e0167412. doi: 10.1371/journal.pone.0167412

Theou, G., Papachristos, D. P., and Stamopoulos, D. C. (2013). Fumigant toxicity of six essential oils to the immature stages and adults of Tribolium confusum. Hell. Plant Prot. J. 6, 29-39.

Tucić, N., Gliksman, I., Šešlija, D., Milanović, D., Mikuljanac, S., and Stojković, O. (1996). Laboratory evolution of longevity in the bean weevil (Acanthoscelides obtectus). J. Evol. Biol. 9, 485-503. doi: 10.1046/j.1420-9101.1996.9040485.x

Valcárcel, F., Olmeda, A. S., González, M. G., Andrés, M. F., Navarro-Rocha, J., and González-Coloma, A. (2021). Acaricidal and insect antifeedant effects of essential oils from selected aromatic plants and their main components. Front. Agron. 3:662802. doi: 10.3389/fagro.2021.662802

Vasantha-Srinivasan, P., Chellappandian, M., Senthil-Nathan, S., Ponsankar, A., Thanigaivel, A., Karthi, S., et al. (2018). A novel herbal product based on Piper betle and Sphaeranthus indicus essential oils: Toxicity, repellent activity and impact on detoxifying enzymes GST and CYP450 of Aedes aegypti Liston (Diptera: Culicidae). J. Asia Pac. Entomol. 21, 1466-1472. doi: 10.1016/j.aspen. 2018.10.008

Wahba, T. F., Mackled, M. I., Selim, S., and El-Zemity, S. R. (2018). Toxicity and reproduction inhibitory effects of some monoterpenes against the cowpea weevil Callosobruchus maculatus F. (Coleoptera: Chrysomelidae: Bruchinae). Middle East J. Appl. Sci. 8, 1061-1070.

Waliwitiya, R., Isman, M. B., Vernon, R. S., and Riseman, A. (2005). Insecticidal activity of selected monoterpenoids and rosemary oil to Agriotes obscurus (Coleoptera: Elateridae). J. Econom. Entomol. 98, 1560-1565. doi: 10.1093/jee/ 98.5.1560

Waliwitiya, R., Nicholson, R. A., Kennedy, C. J., and Lowenberger, C. A. (2012). The synergistic effects of insecticidal essential oils and piperonyl butoxide on biotransformational enzyme activities in Aedes aegypti (Diptera: Culicidae). J. Med. Entomol. 49, 614-623. doi: 10.1603/ME10272

Wang, J. L., Li, Y., and Lei, C. L. (2009). Evaluation of monoterpenes for the control of Tribolium castaneum (Herbst) and Sitophilus zeamais Motschulsky. Nat. Prod. Res. 23, 1080-1088. doi: 10.1080/14786410802267759

Wang, W., Gao, C., Ren, L., and Luo, Y. (2020). The effect of longwave ultraviolet light radiation on Dendrolimus tabulaeformis antioxidant and detoxifying enzymes. Insects 11:1. doi: 10.3390/insects11010001

Wilson, J. A., and Isman, M. B. (2006). Influence of essential oils on toxicity and pharmacokinetics of the plant toxin thymol in the larvae of Trichoplusia ni. Can. Entomol. 138, 578-589. doi: 10.4039/n06-801

Wu, D., Scharf, M. E., Neal, J. J., Suiter, D. R., and Bennett, G. W. (1998). Mechanisms of fenvalerate resistance in the German cockroach, Blattella germanica (L.). Pestic. Biochem. Physiol. 61, 53-62. doi: 10.1006/pest.1998.2343

Yang, H., Piao, X., Zhang, L., Song, S., and Xu, Y. (2018). Ginsenosides from the stems and leaves of Panax ginseng show antifeedant activity against Plutella xylostella (Linnaeus). Ind. Crops Prod. 124, 412-417. doi: 10.1016/j.indcrop. 2018.07.054

Yeom, H. J., Kang, J. S., Kim, G. H., and Park, I. K. (2012). Insecticidal and acetylcholine esterase inhibition activity of Apiaceae plant essential oils and their constituents against adults of German cockroach (Blattella germanica). J. Agric. Food Chem. 60, 7194-7203. doi: 10.1021/jf302009w

Yotavong, P., Boonsoong, B., Pluempanupat, W., Koul, O., and Bullangpoti, V. (2015). Effects of the botanical insecticide thymol on biology of a braconid, Cotesia plutellae (Kurdjumov), parasitizing the diamondback moth, Plutella xylostella L. Int. J. Pest Manag. 61, 171-178. doi: 10.1080/09670874.2015. 1030001

Youssefi, M. R., Tabari, M. A., Esfandiari, A., Kazemi, S., Moghadamnia, A. A., Sut, S., et al. (2019). Efficacy of two monoterpenoids, carvacrol and thymol, and their combinations against eggs and larvae of the West Nile vector Culex pipiens. Molecules 24:1867. doi: 10.3390/molecules24101867

Zahran, H. E. D. M., and Abdelgaleil, S. A. (2011). Insecticidal and developmental inhibitory properties of monoterpenes on Culex pipiens $\mathrm{L}$. (Diptera: Culicidae). J. Asia Pac. Entomol. 14, 46-51. doi: 10.1016/j.aspen.2010.1 1.013

Zhang, S., Wang, X., Gu, F., Gong, C., Chen, L., Zhang, Y., et al. (2020). Sublethal effects of triflumezopyrim on biological traits and detoxification enzyme activities in the small brown planthopper Laodelphax striatellus (Hemiptera: Delphacidae). Front. Physiol. 11:261. doi: 10.3389/fphys.2020. 00261

Zhao, P., Wang, Y., and Jiang, H. (2013). Biochemical properties, expression profiles, and tissue localization of orthologous acetylcholinesterase-2 in the mosquito, Anopheles gambiae. Insect Biochem. Mol. Biol. 43, 260-271. doi: 10.1016/j.ibmb.2012.12.005

Zhu, K. Y., and Brindley, W. A. (1990). Properties of esterases from Lygus hesperus Knight (Hemiptera: Miridae) and the roles of the esterases in insecticide resistance. J. Econ. Entomol. 83, 725-732. doi: 10.1093/jee/83.3.725

Zibaee, A. (2011). "Botanical insecticides and their effects on insect biochemistry and immunity," in Pesticides in the Modern World-Pests Control and Pesticides Exposure and Toxicity Assessment, ed. M. Stoytcheva (London: InTech), $55-68$.

Conflict of Interest: The authors declare that the research was conducted in the absence of any commercial or financial relationships that could be construed as a potential conflict of interest.

Publisher's Note: All claims expressed in this article are solely those of the authors and do not necessarily represent those of their affiliated organizations, or those of the publisher, the editors and the reviewers. Any product that may be evaluated in this article, or claim that may be made by its manufacturer, is not guaranteed or endorsed by the publisher.

Copyright (C) 2022 Lazarević, Jevremović, Kostić, Vuleta, Manitašević Jovanović, Kostić and Šseslija Jovanović. This is an open-access article distributed under the terms of the Creative Commons Attribution License (CC BY). The use, distribution or reproduction in other forums is permitted, provided the original author(s) and the copyright owner(s) are credited and that the original publication in this journal is cited, in accordance with accepted academic practice. No use, distribution or reproduction is permitted which does not comply with these terms. 